\title{
Inventory Investment and the Cost of Capital ${ }^{*}$
}

\author{
Christopher S. Jones \\ Marshall School of Business \\ University of Southern California \\ Los Angeles, CA 90089 \\ christopher.jones@marshall.usc.edu \\ 213-740-9485
}

\author{
Selale Tuzel \\ Marshall School of Business \\ University of Southern California \\ Los Angeles, CA 90089 \\ tuzel@usc.edu \\ 213-740-9486
}

January 2009

${ }^{*}$ We have benefitted from conversations with Neng Wang, Michael Roberts, and Simon Gilchrist, and we are especially grateful to Oguz Ozbas and Vincenzo Quadrini for many insightful discussions. 


\title{
Inventory Investment and the Cost of Capital
}

\begin{abstract}
We examine the relation between inventory investment and the cost of capital in a theoretical model and empirically using data from 1958 to 2006. We analyze a standard real business cycle model with two types of capital goods, fixed capital and inventory. Fixed capital is costly to adjust but depreciates slowly, while inventory can be changed freely but depreciates more quickly. We find that the lack of adjustment costs makes inventory investment less risky, but in calibrations this effect is more than offset by the effect of a higher depreciation rate, which makes inventory riskier than fixed capital. In support of this result, our empirical work documents that risk premia, rather than real interest rates, are negatively related to future inventory growth. This relation is highly significant and robust to a number of variations in estimation method, inventory type, and risk premia proxy. Furthermore, the effect is stronger for durable goods, whose sales are highly procyclical, than for nondurables, and for industries whose sales are more procyclical.
\end{abstract}

JEL classification: E32, E44, G31

Keywords: Inventory Investment, Return Predictability 


\section{Introduction}

As a form of investment, a firm's optimal inventory stock should naturally be expected to vary with its cost of capital. At a macro level, we would expect aggregate inventory investment to vary with measures of the average cost of capital. One of the puzzling results from the empirical macroeconomic literature on inventories is the apparent lack of relation between the accumulation of inventories and the cost of capital, at least as proxied by short-term real interest rates. Maccini, Moore, and Schaller (2004) note that although there is a "perception of an inverse relationship between inventory investment and interest rates, ... almost no evidence exists for such an effect."

The inability to relate inventory investment to the cost of capital is disconcerting given the importance of inventory investment over the business cycle. Table 1 shows that inventory investment, as a fraction of GDP, is more volatile than fixed investment or consumption, and it is strongly procyclical. As many other authors have noted, the typical decline in GDP during a recession is almost exactly accounted for by the contemporaneous decline in inventories. Understanding the cycles in inventories is therefore central to understanding the cycles in output.

A potential shortcoming of prior work is that it generally focuses on the real interest rate as the cost of capital relevant for determining inventory investment decisions. This assumption has obvious appeal, given that it is likely that much inventory investment is financed by short-term borrowing, either in the form of bank loans or commercial paper issuance. Nevertheless, it is incorrect if inventory investment is risky, that is, if returns to inventory investment are correlated with the stochastic discount factor. Basic corporate finance tells us that firm value maximization requires that the manager make inventory investment decisions with a cost of capital that is commensurate with the riskiness of that investment. In particular, the cost of capital that should be used is the same as what a stand-alone firm - a firm whose only investment was that same inventory - would face when raising money to fund that investment. ${ }^{1}$

Viewed this way, it is not at all obvious what cost of capital is appropriate for making inventory decisions. While many types of inventories, like food or tobacco, would appear to carry little systematic risk, other types may be risky for a number of reasons. The value of commodity-like inventories, for instance, might fluctuate substantially with macroeconomic growth. Other goods, like automobiles, which are held in finished goods inventory for longer amounts of time, may face considerable demand risk over the period from when

\footnotetext{
${ }^{1}$ The direct cost of borrowing is not low because inventory investment is not risky, but because the debt is effectively collateralized with the assets of the entire firm. Were the firm to undertake any small investment, no matter how risky, it is likely that they would be able to obtain financing at the same low rates. This does not make that rate the correct cost of capital.
} 
they are produced until when they are sold. This demand risk may be even more substantial for work in progress inventories of goods that require a substantial amount of time to produce.

If inventories are risky, then the real interest rate used in prior work may be a poor proxy for the relevant cost of capital. Over the last several decades, the asset pricing literature has documented substantial variation in risk premia, both in stock and bond returns, and this variation may dwarf that found in the real shortterm interest rate. In bond markets, work starting with Fama and Bliss (1987) and Campbell and Shiller (1991) documented extensive levels of predictability in excess bond returns, much of it correlated with the term spread. More recently, Cochrane and Piazzesi (2005) find that up to $44 \%$ of the variation in one-year excess returns is predictable, suggesting that bond risk premia may change substantially from one month to the next. The literature on stock market predictability is no less convincing, having documenting significant variation in expected returns that is correlated with variables including the dividend yield, the default spread, and the term spread (e.g. Keim and Stambaugh (1986) and Fama and French (1989)).

In contrast, volatility in real rates was quite low over much of the post-war sample period. With a dataset covering 1953-1971, for instance, Fama (1975) fails to reject the hypothesis of constant ex ante real rates. While subsequent rates have proved significantly more volatile, it is possible that they may still represent the least volatile component of the average firm's cost of capital. If the riskiness of inventories approaches the riskiness of the average firm, then the variation in the real interest rate might be only weakly related to the appropriate cost of capital.

An alternative explanation for the lack of any response to real interest rates is the presence of financing constraints. Kashyap, Stein, and Wilcox (1993) investigated this possibility at the aggregate level and found that a proxy for bank loan supply help predict inventory growth. Studies examining inventory patterns and financial constraints in the cross-section of firms include Gertler and Gilchrist (1994), Kashyap, Lamont, and Stein (1994), and Carpenter, Fazzari, and Petersen (1994). All three of these papers document some relationship between a firm's balance sheet and its future inventory investment. Together, these results suggest that there is variation in the effective cost of capital that is not captured by observed short-term interest rates.

Whether or not inventories are in fact risky is something we investigate directly in a theoretical model and indirectly in our empirical work. Our model builds off the classic dynamic production economy of Kydland and Prescott (1982) and Christiano (1988). In their model, production requires investment in both capital goods and inventories. An aggregate productivity shock makes investment in both risky, and the utility function of a representative consumer determines how this risk is priced in equilibrium. Like Kydland and Prescott, we introduce a friction into the adjustment of the capital stock, but we replace Kydland and 
Prescott's time-to-build constraint with a simple adjustment cost that has the effect of smoothing aggregate capital. Somewhat differently from their model, we allow for inventories to depreciate, and in our calibrations we assume this depreciation is at a rate that exceeds that of capital.

In our model, as is standard, the value of the firm is simply the sum of the values of the capital and inventory owned by the firm. Thus, assessing the riskiness of inventory relative to the riskiness of the firm as a whole is equivalent to comparing the beta of inventory investment with that of capital investment. Our model provides a plausible range of values for each of these betas, and we find that the beta of inventory is of comparable to or even larger than that of fixed capital. This suggests that the cost of capital appropriate for discounting the returns from inventory investment may be fairly similar to the cost of capital for the firm as a whole. ${ }^{2}$

The key to understanding this result is that the relative riskiness of capital goods and inventories depends on their differences in two dimensions. The first difference comes from the assumption that capital goods depreciate at a lower rate than inventories. The second is that firms are less flexible in adjusting the level of their capital stock than they are in adjusting their inventories. When firms change their capital stock too quickly, they can face considerable adjustment costs. On the other hand, firms are able to adjust inventories freely.

Adjustment costs make it difficult to respond to productivity shocks by changing fixed investment. When productivity shocks are negative, firms are unable to reduce their capital stock easily, and the value of that capital declines. When shocks are positive, then the value of fixed capital rises as new capital can only be added gradually. The effect is to increase the riskiness of fixed relative to inventory investment.

This effect is offset, however, by the faster depreciation rate of inventories. With its longer life-span, an investment in fixed capital is essentially a bet on productivity averaged over a long period of time. In contrast, the payoff to inventory investment depends on productivity shocks that are realized over a shorter horizon. Since productivity follows a mean-reverting process, the averaging effect makes fixed investment less risky because this averaging occurs over a longer period of time. We answer whether or not this effect offsets the effect of adjustment costs in a calibration exercise.

This higher rate of depreciation is supported by a substantial amount of industry research. Richardson (1995) argues that non-interest inventory carrying costs (which are equivalent to depreciation) range from

\footnotetext{
${ }^{2}$ Indeed, leading industry consultants appear to suggest exactly this approach. Dennis Lord, an inventory management consultant, advises that "Any company serious about knowing their carrying costs will use the weighted average cost of capital (WACC) to calculate the inventory capital charge." Timme and Williams-Timme (2003) write that "Given the inherent risk of inventory, we recommend that companies use a weighted average cost of capital (WACC) to calculate the inventory capital charge."
} 
$19 \%$ to $43 \%$ per year, and other trade publications report rates up to $35 \%{ }^{3}$ In contrast, the level of depreciation typically assumed for fixed capital is relatively low, usually in the range of $5 \%$ to $10 \%$ per year. ${ }^{4}$

Building off some loose predictions from the model, but also based on prior empirical work, our empirical analysis investigates the relationship between the cost of equity and debt capital and the growth rate of inventories. We find strong evidence documenting that forecasts of aggregate inventory growth can be improved by adding variables that have been found by the finance literature to forecast future stock and bond returns. Yet, this evidence is difficult to interpret because these same variables also forecast future output growth. Hence, inventory growth may rise when costs of capital are low only because those costs of capital forecast future demand for goods.

We separate these channels with a simple instrumental variables approach. We find that while variables related to the cost of capital clearly affect growth in future sales, they have an additional effect on inventory investment that we interpret as a pure discount rate effect. Specifically, we find that when expected excess bond or stock returns are low, the growth rate of inventories tends to be high. This effect is highly significant and holds for several alternative measures of the cost of capital. In contrast, but in line with most prior literature, we find no relation between ex ante real interest rates and aggregate inventory behavior.

Our empirical work examines both input inventories (raw materials and work in progress) and output inventories (finished goods). It is well known that these two types are qualitatively different. Input inventories are larger and, at least in the case of durable goods, exhibit greater volatility and are more procyclical. These observations are illustrated in Figure 1, in which real durable and nondurable inventories are plotted over our sample period along with shaded areas representing NBER recessions.

Although we find a sensitivity to risk premia for both input and output inventories, the effect is weaker for output inventories. It is possible that output inventories, being finished goods that are ready to be sold, are less risky than input inventories, which take time to transform into final product. This would be consistent with the relative lack of cyclicality we observe in output inventories.

We also find that the effect is larger for durable goods than it is for nondurables. As noted by Yogo (2006), expenditures are more strongly procyclical for durable goods than they are for nondurables. In our

\footnotetext{
${ }^{3}$ The Annual State of Logistics Report from the Council of Supply Chain Management Professionals estimates costs of 19\% annually, while the APICS Dictionary of the Association for Operations Management reports rates from $10 \%$ to $35 \%$. Lord (2008) claims that rates can run as high as $40 \%$ annually, but his figure is a total measure that includes the cost of capital.

${ }^{4}$ Furthermore, note that reported rates are likely averages over many goods types and are therefore endogenous, as firms will tend to hold greater inventories in goods that do not depreciate as quickly. The true exogenous depreciation rates on specific goods types might therefore be expected to be somewhat higher.
} 
sample, the beta of a regression of durable expenditure growth on GDP growth is around 2.5 times as large as the corresponding beta for nondurables. This greater sensitivity to the business cycle should naturally make investment in durable inventories more risky and therefore more sensitive to the level of aggregate risk premia.

We further disaggregate the data by examining inventory growth patterns in 12 different industries. Although we find that the relation between inventory growth and expected risk premia is significant only for about half of these industries, the effect seems to be stronger for those industries, like transportation equipment, whose sales covary most positively with aggregate GDP growth, than for other industries, like food, whose sales are relatively flat across the business cycle. While the results are only suggestive, they reinforce our conclusion that inventory investment is, at least in part, determined by risk-based cost of capital.

In the next section of the paper we introduce a simple general equilibrium model in which firms invest in both capital goods and inventories. Section 3 of the paper solves this model. Our empirical analysis is contained in Section 4, and Section 5 concludes.

\section{Theoretical Model}

Our model is a standard real business cycle model with two types of capital goods: fixed capital (equipment and structures) and inventories (Kydland and Prescott, 1982, and Christiano, 1988). There is a representative firm with CES production technology that faces adjustment costs in fixed capital and a representative agent with standard preferences (power utility) over consumption.

\subsection{The firm and its technology}

There is a representative firm that produces a homogeneous good using both fixed capital and inventories. Any investment in fixed capital is subject to convex adjustment costs, whereas inventories can be adjusted costlessly. ${ }^{5}$ Fixed capital depreciates at rate $\delta$ and inventory depreciates at rate $\lambda$. We assume that fixed capital depreciates slower than inventories, so that $\lambda>\delta$. This is consistent with the average fixed capital depreciation rates from BEA tables and the non-interest inventory carrying cost estimated by inventory management experts.

\footnotetext{
${ }^{5}$ It is widely accepted in the literature that inventory investment has low adjustment cost. Carpenter, Fazzari, and Petersen (1994) characterize inventories as a liquid, readily reversible investment with low adjustment costs. Chirinko (1993) estimates adjustment costs on fixed capital and inventories separately and finds that the adjustment cost parameter on inventories is negative.
} 
We use the production function studied in Kydland and Prescott (1982) and Christiano (1988):

$$
\begin{aligned}
Y_{t} & =F\left(A_{t}, K_{t}, M_{t}, L_{t}\right) \\
& =A_{t}\left((1-\sigma) K_{t}^{-v}+\sigma M_{t}^{-v}\right)^{\frac{-\theta}{v}} L_{t}^{1-\theta},
\end{aligned}
$$

where $Y_{t}$ denotes output, $K_{t}$ the firm's fixed capital stock, $M_{t}$ the firm's inventories, $L_{t}$ the number of hours worked, and $a_{t}=\ln \left(A_{t}\right)$ denotes aggregate productivity. $a_{t}$ has a stationary and monotone Markov transition function, denoted by $p_{a}\left(a_{t+1} \mid a_{t}\right)$, given by

$$
a_{t+1}=\rho_{a} a_{t}+\sigma_{a} \varepsilon_{t+1}^{a}
$$

where $\varepsilon_{t+1}^{a}$ is an IID normal shock. Labor is supplied inelastically and is normalized to $L_{t}=1$. The elasticity of substitution between fixed capital and inventory is $\frac{1}{1+v}$. The two capital goods become perfect substitutes as $v \rightarrow-1$ and perfect complements as $v \rightarrow \infty$. Taking the limit as $v \rightarrow 0$ yields the Cobb-Douglas specification.

The capital accumulation rules for fixed capital and inventory are

$$
\begin{aligned}
& K_{t+1}=(1-\delta) K_{t}+\phi\left(\frac{I_{K, t}}{K_{t}}\right) K_{t} \\
& M_{t+1}=(1-\lambda) M_{t}+I_{M, t},
\end{aligned}
$$

where $I_{K, t}$ and $I_{M, t}$ denote investment in fixed capital and inventories, respectively. The efficiency of capital investment is determined by the function

$$
\phi\left(\frac{I_{K, t}}{K_{t}}\right)=\frac{a}{1-1 / \xi}\left(\frac{I_{K, t}}{K_{t}}\right)^{1-\frac{1}{\xi}}+b,
$$

which will always take values less than $I_{K, t} / K_{t}$. We set $a$ and $b$ so that the firm does not incur adjustment costs when investing at the steady state rate (i.e. to replace depreciated capital). The parameter $\xi$ is the elasticity of the fixed investment-capital ratio $I_{K, t} / K_{t}$ with respect to Tobin's $q$. If $\xi=\infty$, the capital accumulation equation reduces to the standard capital accumulation equation without adjustment costs.

The firm is equity financed. The dividend to shareholders is equal to

$$
D_{t}=Y_{t}-\left[I_{K, t}+I_{M, t}\right]-w_{t} L_{t},
$$

where $w_{t}$ is the wage payment to labor services. Labor markets are competitive, so wage payments are determined by the marginal product of labor.

At each date $t$, the firm chooses $K_{t+1}$ and $M_{t+1}$ to maximize the net present value of their expected dividend stream,

$$
E_{t}\left[\sum_{k=0}^{\infty} \frac{\beta^{k} \Lambda_{t+k}}{\Lambda_{t}} D_{t+k}\right]
$$


subject to (1) and (2), where $\beta^{k} \Lambda_{t+k} / \Lambda_{t}$ is the marginal rate of substitution of the firm's owners between time $t$ and $t+k$.

The pricing equations that are derived from the firm's optimization problem are:

$$
\begin{aligned}
1 & =\int \beta \frac{\Lambda_{t+1}}{\Lambda_{t}} R_{K, t+1} p_{a}\left(a_{t+1} \mid a_{t}\right) d_{a} \\
1 & =\int \beta \frac{\Lambda_{t+1}}{\Lambda_{t}} R_{M, t+1} p_{a}\left(a_{t+1} \mid a_{t}\right) d_{a}
\end{aligned}
$$

where the returns to fixed capital and inventory investment are given by

$$
\begin{aligned}
R_{K, t+1} & =\left(F_{K_{t+1}}+\frac{(1-\delta)+\left(\frac{a}{1-1 / \xi}\left(I_{K, t+1} / K_{t+1}\right)^{1-\frac{1}{\xi}}+b\right)}{a\left(I_{K, t+1} / K_{t+1}\right)^{-\frac{1}{\xi}}}-\frac{I_{K, t+1}}{K_{t+1}}\right) a\left(I_{K, t} / K_{t}\right)^{-\frac{1}{\xi}} \\
R_{M, t+1} & =F_{M_{t+1}}+1-\lambda,
\end{aligned}
$$

and where

$$
\begin{aligned}
& F_{K_{t}}=F_{K}\left(A_{t}, K_{t}, M_{t}, L_{t}\right) \\
& F_{M_{t}}=F_{M}\left(A_{t}, K_{t}, M_{t}, L_{t}\right) .
\end{aligned}
$$

Tobin's $q$, the consumption good value of a newly installed unit of capital, is

$$
\begin{aligned}
& q_{K, t}=\phi^{\prime}\left(\frac{I_{K, t}}{K_{t}}\right)=a\left(\frac{I_{K, t}}{K_{t}}\right)^{-\frac{1}{\xi}} \\
& q_{M, t}=1
\end{aligned}
$$

for fixed capital and inventory, respectively.

Multiplying both sides of pricing equations with $K_{t+1}$ and $M_{t+1}$, respectively, rearranging, and adding the equations leads to:

$$
\begin{aligned}
& q_{K, t} K_{t+1}+q_{M, t} M_{t+1}= \\
& \quad \int \frac{\beta \Lambda_{t+1}}{\Lambda_{t}}\left(q_{K, t+1} K_{t+2}+q_{M, t+1} M_{t+2}+\theta Y_{t+1}-I_{K, t+1}-I_{M, t+1}\right) p_{a}\left(a_{t+1} \mid a_{t}\right) d_{a} .
\end{aligned}
$$

The end of period value of a firm's equity, denoted $V_{t}$, is equal to the market value of its assets in place:

$$
V_{t}=q_{K, t} K_{t+1}+q_{M, t} M_{t+1} .
$$

Replacing equations (8) and (3) in (7) gives the standard Euler equation:

$$
1=\int \frac{\beta \Lambda_{t+1}}{\Lambda_{t}} \frac{V_{t+1}+D_{t+1}}{V_{t}} p_{a}\left(a_{t+1} \mid a_{t}\right) d_{a} .
$$




\subsection{The representative agent}

The representative agent maximizes expected discounted utility. Preferences over consumption take the standard form:

$$
E_{t}\left[\sum_{k=0}^{\infty} \beta^{k} u\left(C_{t+k}\right)\right] \quad u\left(C_{t}\right)=\frac{C_{t}^{1-\gamma}}{1-\gamma} .
$$

The representative agent invests in a riskless one-period bond and a single risky asset, the stock in the firm. At each date $t$, the representative agent must satisfy the budget constraint

$$
b_{t+1} q_{t}^{r f}+s_{t+1} V_{t}+C_{t} \leq s_{t}\left(V_{t}+D_{t}\right)+b_{t}+w_{t} m
$$

where $b_{t+1}$ and $s_{t+1}$ denote holdings of the bond and stock at the end of period $t$. The prices of these assets are given by $q_{t}^{r f}$ and $V_{t}$, respectively. $D_{t}$ denotes period $t$ dividend of the firm, as defined in the previous section.

At each date $t$, the agent chooses $b_{t+1}, s_{t+1}$, and $C_{t}$ to maximize (10) subject to (11). The first order conditions for the representative agent's optimization problem are:

$$
\begin{aligned}
q_{t}^{r f} & =E_{t}\left[\frac{\beta u^{\prime}\left(C_{t+1}\right)}{u^{\prime}\left(C_{t}\right)}\right] \\
1 & =E_{t}\left[\frac{\beta u^{\prime}\left(C_{t+1}\right)}{u^{\prime}\left(C_{t}\right)} \frac{V_{t+1}+D_{t+1}}{V_{t}}\right] .
\end{aligned}
$$

\subsection{Equilibrium}

The state of the economy is characterized by the aggregate productivity $a$ and the capital holdings $K$ and $M$. A competitive equilibrium consists of consumption function, $C(a, K, M)$; investment functions $b^{\prime}(a, K, M)$ and $s^{\prime}(a, K, M)$; policy functions $I_{K}(a, K, M)$ and $I_{M}(a, K, M)$; capital accumulation functions

$K^{\prime}(a, K, M)$ and $M^{\prime}(a, K, M)$; price function for installed fixed capital $q_{K}(a, K, M)$; price function for the firm, $V(a, K, M)$; and a risk free $\operatorname{rate}^{f}(a, K, M)$ that solve the firms' optimization problems (i.e. maximize (4) subject to (1) and (2)), solve the representative agent's optimization problem (i.e. maximize (10) subject to (11)), and satisfy the aggregate resource constraint:

$$
C(a, K, M)+I_{K}(a, K, M)+I_{M}(a, K, M) \leq Y .
$$

\section{Calibration and Quantitative Results}

Solving our model generates equilibrium solutions for macroeconomic aggregates such as output, fixed and inventory investment, and consumption. Our primary interest, however, is in assessing the riskiness of 
inventory investment relative to the riskiness of the more commonly considered type of investment, fixed investment. We will perform this assessment by comparing the "beta" of the inventory investment with that of the fixed capital investment, where beta is measured with respect to the representative agent's marginal rate of substitution. I.e., the risk of investing in a generic type of capital $i$ is equal to

$$
\frac{-\operatorname{Cov}_{t}\left(\frac{\beta \Lambda_{t+1}}{\Lambda_{t}}, R_{i, t+1}\right)}{\operatorname{Var}_{t}\left(\frac{\beta \Lambda_{t+1}}{\Lambda_{t}}\right)}
$$

We calibrate the model to the data. In the data, we measure consumption, fixed investment, inventories and output similar to Christiano (1988). Capital for our model reflects all tangible capital, including government and privately owned stocks of plant and equipment, housing and consumer durables. Consumption includes the consumption of nondurables and services and government consumption. Investment is measured as fixed investment plus consumption of durable goods and government investment. Inventories are all private inventories, sum of farm and nonfarm inventories.

Table 2 presents the parameters used in the calibration and simulations of the model economy together with the model implied investment volatilities and betas. Following Kydland and Prescott (1982), the capital share $\alpha$ is set to 0.36. Again following Kydland and Prescott (1982), we assume a subjective time discount rate of four percent annually ( $\beta=0.99$ quarterly) and abstract from growth. The coefficient of relative risk aversion $\gamma$ is set to 2. The depreciation rate for fixed capital is set to eight percent annually $(\delta=0.02$ quarterly), which is roughly the midpoint of values used in other studies. Cooley and Prescott (1995) use 1.6\%, Boldrin, Christiano and Fisher (2001) use 2.1\%, and Kydland and Prescott (1982) use a 2.5\% quarterly depreciation rate. The empirical estimates for the depreciation rate of inventories $(\lambda)$ ranges from $20 \%$ to $40 \%$. We will allow this parameter to vary in different specifications. Similar to Kydland and Prescott (1982), we require $v$ and $\sigma$ to be such that the steady state ratio of the two capital goods, $K / M$ is equal to 10. We will allow $v$ (and thus the elasticity of substitution between fixed capital and inventories) to vary in simulations. Similarly, we will allow the adjustment cost parameter $\xi$ to vary in different specifications. The persistence and the conditional volatility of the aggregate productivity process, $\rho_{a}$ and $\sigma_{a}$, are picked such as to replicate the consumption and output growth volatility in the data, $0.60 \%$ and $1.16 \%$ respectively. In the baseline parameterizations, we will pick $\xi$ and $\lambda$ such as to replicate the fixed investment and inventory growth volatility in the data, which are $2.40 \%$ and $0.74 \%$, respectively.

Panel C of Table 2 represent three calibrations that each match (to a close approximation) the observed volatilities in the growth rates of fixed investment, inventories, consumption, and output. Matching the volatility of fixed investment and inventories requires inventory depreciation rates that are slightly higher than the empirical estimates of nonfinancial inventory holding costs. The minimum inventory depreciation 
rates implied by the economy calibrated to match the volatilities is around $15 \%$ quarterly. As we reduce this depreciation rate, calibration requires lowering the investment adjustment costs (higher $\xi$ ), but once depreciation is at $15 \%$ the adjustment costs are already quite low, so decreasing them further has little effect.

Calibrations of the model to the volatility of the macroeconomic aggregates yield somewhat higher betas for inventory investment relative to fixed capital investment. To gain some intuition about these betas, we perform a sequence of comparative statics in which we change one parameter at a time. These are reported in Panels D, E, and F of the table.

Panel D varies the parameter $v$. Higher values of $v$ lower the elasticity of substitution between the two types of capital. This increases the volatility of fixed investment while lowering the volatility of inventories, which leads to higher fixed investment betas but has little effect on inventory betas.

In Panel E we experiment with lower values of $\xi$, implying higher adjustment costs for fixed capital. As fixed investment becomes more difficult to adjust, its beta increases dramatically, reflecting the riskiness that arises from the inability to respond freely to productivity shocks. At the same time, inventory betas fall slightly.

Finally, Panel F examines the effects of changing the inventory depreciation rate. This parameter turns out to be extremely important in determining the relative riskiness of inventory and fixed investment. With high depreciation, the inventory investment beta is twice that of fixed investment. With low depreciation, this relation is reversed. Intuitively, both forms of investment are sensitive to the average productivity realized over their life spans. Because productivity is a mean reverting process, its average becomes less volatile as the horizon increases. Thus, the higher depreciation rate of inventories makes inventory investment more risky because it represents a bet on short-term rather than long-term productivity.

Overall, these results demonstrate that the riskiness of inventory investment may be comparable to or even exceed that of fixed capital. From our perspective, the exact magnitudes of the two betas is less important than the finding that inventory betas can indeed be sizeable, certainly far enough above zero to suggest that risk premia may be relevant in computing their cost of capital. In addition, the model provides an intuitive explanation of the determinants of the riskiness of these two forms of investment, that adjustment costs to fixed investment naturally make them more risky, but that this effect is offset by the high depreciation rate of inventories that makes them an "all-or-nothing" bet on near-term productivity. 


\section{Empirical Analysis}

Our interest is in the empirical relation between inventory investment and the cost of capital, controlling for other factors that past theory or empirical work has found to be relevant. If possible, we would run regressions such as

$$
\Delta \ln M_{t}=\gamma_{0}+\gamma_{1} \ln \left(M_{t-1} / X_{t-1}\right)+\delta_{1} \mathrm{E}_{t-1}\left[\Delta \ln X_{t}\right]+\delta_{2} \mathrm{E}_{t-1}\left[R F_{t}\right]+\delta_{3} \mathrm{E}_{t-1}\left[R P_{t}\right]+\epsilon_{t},
$$

where $M_{t}$ denotes input inventories at the end of month $t, X_{t}$ denotes month- $t$ sales, $R F_{t}$ is the ex post real rate of return on a short-term nominal bond, and where $R P_{t}$ denotes some measure of risk premia, typically the excess return on a portfolio of stocks or bonds.

Each term in the regression has a simple interpretation. The ratio of past inventories to sales, $M_{t-1} / X_{t-1}$, arises as in Lovel (1961) from a target adjustment motive, and we would expect a negative coefficient on this term. The effect of higher expected sales growth, $\mathrm{E}_{t-1}\left[\Delta \ln X_{t}\right]$, is somewhat indeterminate. If inventories are primarily used to smooth production, then we might expect $\delta_{1}$ to be negative. If, on the other hand, inventories serve mainly to avoid stock-outs, then $\delta_{2}$ should be positive. Finally, the two components of the cost of capital, $\mathrm{E}_{t-1}\left[R F_{t}\right]$ and $\mathrm{E}_{t-1}\left[R P_{t}\right]$, are included given the focus of our paper.

We note that it is impossible to compress the terms $\mathrm{E}_{t-1}\left[R F_{t}\right]$ and $\mathrm{E}_{t-1}\left[R P_{t}\right]$ into one single regressor representing the total cost of capital. Were we able to observe returns on inventory investment, we could measure empirically the "beta" of inventory investment and then conclude that the theoretically correct cost of capital would be $\mathrm{E}_{t-1}\left[R F_{t}\right]+$ beta $\times \mathrm{E}_{t-1}\left[R P_{t}\right]$. Since these returns are not available to us, we must include the real interest rate and risk premium as separate regressors.

The challenge in estimating the model above is clearly in the unobservability of the expectations on the right hand side of the regression. Below we address this issue with two different instrumental variables methods after explaining why a simpler approach is inappropriate.

\subsection{Data}

Our primary data source is the Manufacturers' Shipments, Inventories, and Orders (M3) database from the U.S. Census. From this database we obtain monthly values for aggregate and disaggregate sales (shipments) and inventories. The data are available in seasonally-adjusted form, but they are nominal. We compute real series using the appropriate Producer Price Index from the Bureau of Labor Statistics.

We use shipment data for all manufacturing goods, durables and nondurables separately, and for 12 different industries. The database contains total inventories corresponding to each of these shipments series. 
It also contains unfilled orders for most durable goods industries and, through March 2001, for aggregate nondurable goods. For all manufacturing, durable, and nondurable goods we also have inventories separated into raw materials, work in progress, and finished goods. Following Humphreys, Maccini, and Schuh (2001) we refer to the sum of raw materials and work in progress as "input" inventories and to finished goods as "output inventories."

We augment this dataset with financial asset returns and predictive variables from several sources. Nominal riskless returns and excess stock returns are from the website of Ken French. The returns on long-term corporate and Treasury bonds are from Ibbotson and Associates. Real risk free returns are computed by subtracting CPI growth from French's nominal returns.

We compute the term spread as the difference between the 10-year and 3-month Treasury yields. These data are from the Federal Reserve's H15 database. Prior to 1962 we use monthly averages, but starting in 1962 we use month-end values. The default spread is computed as the difference between Moody's average BAA bond yield and the 10-year Treasury yield. These are also obtained from H15 data, but both yields are monthly averages.

We compute the earnings/price ratio as the 1-year moving average of past S\&P Composite earnings divided by the current level of the S\&P Composite Index, where both data series are from from Robert Shiller's website. Finally, we make limited use of a GDP growth rate series computed from the quarterly per capita real GDP series from the Bureau of Economic Analysis NIPA tables. We also use the ratio of patents to shipments (over the period from 1980 to 1998) as a measure of how fast an industry's products become obsolete. The source of these data is the U.S. Patent and Trademark Office. Additional details on data construction can be found in our appendix. ${ }^{6}$

\subsection{An OLS approach}

One approach to specifying a feasible counterpart to (13) is to replace the expected value of each variable with lagged regressors known to predict those variables. Ex post real interest rates, for instance, are known to be at least somewhat persistent (e.g. Nelson and Schwert (1977)), so we could proxy for $\mathrm{E}_{t-1}\left[R F_{t}\right]$ with $R F_{t-1}$. For our risk premium variable, we choose $R B R F_{t}$, the excess return on a portfolio of corporate bonds. As noted above, these excess returns are predicted by the slope of the term structure. As we will see, there is some additional predictability related to the lagged ex post real interest rate, so we can

\footnotetext{
${ }^{6}$ Data sources:

French: mba.tuck.dartmouth.edu/pages/faculty/ken.french/data_library.htm

Shiller: www.econ.yale.edu/ shiller/data.htm
} 
replace $\mathrm{E}_{t-1}\left[R B R F_{t}\right]$ with some linear combination of $T E R M_{t-1}$ and $R F_{t-1}$. Finally, we will see below that expected sales growth, $\mathrm{E}_{t-1}\left[\Delta \ln X_{t}\right]$, is predicted by a number of variables, including several of its own lags.

The top two lines of Table 3 demonstrate the predictability of excess corporate bond returns. Using our entire sample period, we regress monthly values of $R B R F$ on the lagged values of the ex post real interest rate and the term structure slope, i.e.

$$
R B R F_{t}=\alpha_{0}+\alpha_{1} R F_{t-1}+\alpha_{2} T E R M_{t-1}+\eta_{t}
$$

The t-statistics in parentheses are computed using Newey-West (1987) standard errors using 12 lags.

As in previous literature, we find a highly significant positive value for $\hat{\alpha}_{2}$, but we find a significantly positive $\hat{\alpha}_{1}$ as well. The adjusted R-squared in this regression is around $5 \%$, which is in line with prior work that examines monthly returns (e.g. Fama and French (1989)).

Based on these results, we run a forecasting regression in which inventory growth is predicted via lagged values of sales growth, the lagged inventory/sales ratio, and the lagged ex post real interest rate. We compare this regression to another that is identical except that the term structure slope is included as an additional regressor, resulting in the following regression equation:

$\Delta \ln M_{t}=\beta_{0}+\beta_{1} \Delta \ln X_{t-1}+\beta_{2} \Delta \ln X_{t-2}+\beta_{3} \Delta \ln X_{t-3}+\beta_{4} \ln \left(M_{t-1} / X_{t-1}\right)+\beta_{5} R F_{t-1}+\beta_{6} T E R M_{t-1}+\epsilon_{t}$

The results, in the middle of Table 3 , show that TERM is highly significant and that including it in the regression more than doubles the adjusted R-squared. The negative sign of the coefficient is consistent with the inverse relation we would expect between costs of capital and investment quantities. In contrast, but in line with most prior literature, the lagged real rate has no significant relation to future inventory growth. This is the case whether or not TERM is included in the regression.

The shortcoming of this regression approach is that it is not at all clear whether the significance of TERM represents a pure cost of capital effect, or whether TERM simply captures a component of expected sales growth that is orthogonal to the sales growth lags that are included in the regression. The last two lines of Table 3 demonstrates that this is a real concern. In this regression, we simply replace the dependent variable of the previous regression, $\Delta \ln M_{t}$, with the growth rate in future sales, or $\Delta \ln X_{t}$. We find that $T E R M$ has a highly significant coefficient in this regression as well, but it now appears with a positive coefficient. It is therefore possible that higher values of TERM imply a higher sales forecast than would be implied by the other variables in the model. If inventories are used to smooth production, then this effect would naturally lead to a decrease in the expected inventory growth rate. Separating out these two channels requires a slightly different approach, which we describe in the next subsection. 


\subsection{Empirical method}

Because of issues surrounding the difficulty in interpreting TERM in regressions like those in the previous section, our primary empirical method estimates models such as (13) directly via two-stage least squares. We consider two variants of this approach, one of which is completely standard. All predetermined variables are used as instruments, making the two-stage least squares approach equivalent to instrumental variables.

Using all potential instruments in each first stage regression is optimal, at least in large samples, but it is possibly unattractive for three reasons. First, many of the instruments may be irrelevant for predicting some of the endogenous variables - the third lag of sales growth, for instance, is probably unimportant for predicting future stock market returns. Given weak relations like this, restricting some of the first stage regressions could result in stronger finite sample inference.

In addition, allowing the excess market return, for instance, to depend on variables like past sales growth would make our proxies for the cost of capital inconsistent with a large finance literature that does not consider such variables. Even if our approach is slightly inefficient, it has the advantage of greater comparability with previous work.

Lastly, the standard instrumental variables approach is somewhat problematic when comparing alternative model specifications. Below we will compare, as an example, the behavior of durable inventories to that of nondurables. When doing so we will naturally change the measure of lagged inventories that appears as an explanatory variable in that regression. In a standard IV approach, this has the effect of changing the first-stage predictions of all the endogenous variables, including our cost of capital measures. This makes it difficult to tell whether durables and nondurable inventories actually have different behavior, or instead whether one is merely better at forecasting future returns on the market portfolio.

Because of all these issues our primary results will be from regressions in which first-stage regressions use different subsets of all available instruments. As we discuss below, these subsets will be chosen by minimizing the Akaike information criterion. In the interest of maintaining large sample optimality and checking robustness, we will in addition report standard IV regression results for most of our specifications.

Whether or not instruments are equation-specific, estimates are still obtained by two-stage least squares. The standard IV-based approach for computing standard errors no longer applies, however, when instruments vary across first-stage regressions. In this case, we use Pagan's (1984) approach for computing standard errors in models, like ours, that contain generated regressors. In both methods, we allow for heteroskedasticity and autocorrelation in the residuals by using the Newey-West (1987) covariance matrix with 12 lags. 


\subsection{Predictive regressions}

Our empirical approach requires instruments that have predictive power for the endogenous variables in our model. In this section we investigate predictability in sales growth, real riskless returns, and excess returns on portfolios of risky assets. The sales growth measure we consider is computed from the sales of all manufacturing goods. Below we will also look at durables and nondurables separately. When we do our instrument set will be identical to the one we use for all goods, except that we will compute the sales and inventory measures we require using only durables or nondurables.

Our approach, with two exceptions noted below, is to select those instruments that minimize the Akaike information criterion. We search over all possible combinations of predictive variables from a set that includes three lags of sales growth and the logarithm of the lagged inventory/sales ratio (using manufacturers' input inventories). We also include five predictive variables related to lagged asset prices. The first is the lagged real return on a nominally riskless asset, and the second is a 12-month moving average of this variable that is included to capture trends in real rates. The rest are the term spread, the default spread, and the earnings/price ratio, all described above in the Data section. ${ }^{7}$

Table 4 reports the results of this process. The top part of the table contains results for the sales growth regressions. The first regression is the specification that minimizes the AIC. ${ }^{8}$ The second regression includes all available instruments.

Interestingly, sales growth is negatively related to its one-month lag, a result that we find even when that lag is the only explanatory variable in the regression. Only the third lag of sales growth is significant with a positive sign. The lagged inventory/sales ratio is also significant and positively related to future sales. Finally, the coefficients on TERM and EP, the earnings/price ratio, are also highly significant, indicating the ability of financial variables to forecast economic growth, similar to results widely reported in the literature (e.g. Harvey (1988) or Ang, Piazzesi, and Wei (2006)).

The next two regressions are identical except that the inventory/sales ratio is detrended by fitting a constant and a time trend to the original ratio and subtracting out the fitted value. We report these results because it is well-known from prior work that aggregate inventory stocks have generally fallen throughout our sample period. While linear detrending may not be appealing to many readers, the results in Table 4 at least suggest that few inferences are sensitive to removing the trend in inventories. Furthermore, we obtain similar results both by detrending with the Hodrick-Prescott filter and by including a time trend directly in

\footnotetext{
${ }^{7}$ Note that we do not include Lettau and Ludvigson's (2001) cay variable since it is only available quarterly.

${ }^{8}$ Actually, the specification that minimized the AIC did not include the second lag of sales growth, which we viewed as unreasonable. We therefore minimized the AIC subject to this lag being included.
} 
the sales growth regressions.

The remainder of the table contains results on the predictability of various components of the ex post cost of capital. In order to produce cost of capital measures that are consistent with previous literature, we focus on predictors popular in prior literature and specifically exclude non-financial variables (lagged sales growth and inventory/sales ratios) when finding the minimum AIC instrument sets.

For regressions of real returns on nominal one-month bonds, the specification that minimizes the AIC includes both the first lag of $R F$, its lagged 12-month moving average, and the term spread, though only the first two regressors are statistically significant. Adding the remaining instruments to the regression does not result in much improvement in fit, with the adjusted R-squared falling slightly.

The second panel of the table examines predictive regressions for $R B R F$, the excess return on corporate bonds, $R M R F$, the excess market return, and $R B R T$, the return on corporate bonds minus the return on long-term Treasuries. We include the latter series to try to isolate the component of the corporate bond return that is unrelated to movements in the term structure of Treasury yields.

For $R B R F$, the most important financial predictors are $R F$ and $T E R M$. Interestingly, sales growth also appears to be significant at the first and second lag, and including the full set of instruments raises the adjusted R-squared from 0.050 to 0.067 . It is also notable that we do not find the default spread variable $D E F$ to be important for predicting future excess corporate bond returns.

The default spread does turn out to be important for predicting $R B R T$, suggesting that this measure of excess returns is less related to movements in the Treasury yield curve and more to movements in aggregate credit risk. Following much previous work, the model for $R M R F$ includes lagged $R F, T E R M$, and $E P$, though the coefficient on EP is insignificantly different from zero. None of the non-financial variables turn out to be significant either for $R B R T$ or $R M R F$.

Since fitted values from these regressions represent different components of the cost of capital, it is straightforward to examine which measures exhibit the greatest variation. Figure 2 plots the fitted values of $R F, R B R F$, and $R M R F$ from the regressions that use our preferred instrument sets. What is immediately apparent is the lack of variation in the ex ante real rate relative to the expected risk premia. It is also apparent that the expected bond and stock premia are highly correlated, with a coefficient of 0.88 . Their correlations with the ex ante real rate are much lower, with both between 0.4 and 0.5.

Fitted values of $R B R T$ are not plotted, but they differ substantially with the other series, being most correlated (with a coefficient of 0.42 ) to the fitted values of $R B R F$. Unlike $R B R F$ or $R M R F$, variation in the expected values of $R B R T$ is low, with a standard deviation that is only about three quarters as large as the expected values of $R F$. 


\subsection{Results for aggregate inventories}

Table 5 contains the paper's main empirical result. Regardless of which measure of risk premia is used, and whether or not the log inventory/sales ratio is detrended, higher risk premia predict lower growth rates in manufacturing input inventories. The only difference between the two panels in the table is that Panel A uses equation-specific instruments (with Pagan/Newey-West standard errors) while Panel B uses all available instruments (with regular IV/Newey-West standard errors).

The choice of instruments generally has little effect on our results. The only variable that is reliably significant is the risk premium. In some specifications, expected future sales is positively related to inventory growth. When $\ln (M / X)$ is detrended, it generally appears with a negative coefficient that is statistically significant about half the time. The ex ante real rate does not have a significant effect in any of the regressions.

Table 6 repeats this analysis using manufacturing output (i.e. finished goods) inventories, which we denote as $N_{t}$. Coefficients on the three risk premia variables are still generally negative, but statistical significance is lost when all instruments are used and the log inventory/sales ratio (now $\ln (N / X)$ ) is detrended. Few of the other parameters are statistically significant, with the coefficient on expected future sales almost always insignificantly positive and the coefficient on lagged $\ln (N / X)$ significantly negative for most of the regressions using detrended data. Again, the real rate has no effect.

As noted in the introduction, durable expenditures are much more sensitive to the business cycle than nondurables. A regression of durable expenditure growth on GDP growth reveals a slope coefficient around 2.5 times as large as the corresponding coefficient for nondurables. In addition, delivery lead times (as approximated by the ratio of unfilled orders to shipments) are also much higher for durables than they are for nondurables. Over the 1968-2001 period, the longest sample for which nondurable unfilled orders are available, the average ratio of unfilled orders to shipments is just 0.73 for nondurables, indicating a lead time of around three weeks. For durables, over the same period, that figure is around four months. With longer lead times, durable goods producers are more exposed to changes in business conditions because they are less able to slow inventory growth by cutting production. Combined, these factors suggest that investment in durable goods may be significantly riskier and, therefore, more sensitive to the cost of capital. We examine this prediction in Table 7 .

The results are unambiguous that durable inventory growth has a much greater response to changing risk premia than do nondurables. This result holds for all four of the specifications we consider in these two tables. Furthermore, although we report only those results where risk premia are proxied by $\mathrm{E}_{t-1}\left[R B R F_{t}\right]$, nearly identical and equally convincing results are obtained with $\mathrm{E}_{t-1}\left[R B R T_{t}\right]$ and $\mathrm{E}_{t-1}\left[R M R F_{t}\right]$.

Table 8 repeats this analysis with manufacturers output inventories. The results here are, unfortunately, 
less clear. When $\ln (N / X)$ is not detrended, then we get the same result as for input inventories that durables are more sensitive to the cost of capital. With detrending, this conclusion no longer holds, and results using $\mathrm{E}_{t-1}\left[R B R T_{t}\right]$ and $\mathrm{E}_{t-1}\left[R M R F_{t}\right]$ are no more conclusive.

\subsection{Results for industries}

Our final empirical results concern the behavior of inventory growth rates at the industry level. As discussed above, we have inventory data from 12 industries (based on 2-digit SIC codes), and these inventories cannot be disaggregated into inputs and outputs. Six of these industries categorized as producing nondurables (food, tobacco, paper, chemicals, petroleum products, rubber), and six produce durables (stone/clay/glass, primary metals, fabricated metals, industrial machinery, electronic equipment).

The results of estimating (13) on industry-level total inventories appear in Table 9. We report only those results with equation-specific instruments and risk premia proxied by $\mathrm{E}_{t-1}\left[R B R F_{t}\right]$, but results that use all instruments or other risk premia specifications are very similar. The table also includes several variables that we believe should be related to the riskiness of inventory investments. The first, the "GDP beta," is simply the slope coefficient of a regression of quarterly sales growth (where quarterly sales is the sum of monthly sales) on quarterly growth in per capita GDP. This regression is run completely independently of our model for inventory growth. Second is the average delivery lead time, computed as the ratio of unfilled orders to shipments. Because longer lead times make it more difficult to adjust inventories by changing production, firms with longer lead times should be more sensitive to economic activity. Finally, we include the average ratio of patents to shipments as a measure of the rate of product obsolescence. An inventory that is quick to become obsolete, even if it has not depreciated physically, should compound the effect of any decline in business conditions.

The estimated coefficient on $\mathrm{E}_{t-1}\left[R B R F_{t}\right]$ is negative in 10 out of 12 cases but statistically significant in only five. Four of these five significant coefficients are found for industries producing durable goods. The coefficients on the two non-financial variables are usually insignificant, with the exception of a highly significant positive relation between expected petroleum sales and inventory growth. The coefficient on the ex ante real rate is significant in five out of 12 industries, but it is positive for four of those cases.

What is most interesting, however, is the relation between GDP betas and the coefficient on $\mathrm{E}_{t-1}\left[R B R F_{t}\right]$. Figure 3 plots the relation between the two, and though we are unable to make formal conclusions about this relationship with just 12 data points, the observed relation appears strongly negative. Though we do not believe that our GDP beta measure is the only - or even most important - measure of the riskiness of inventory investment, this result at least suggests that riskier types of inventory investment respond more 
strongly to fluctuations in aggregate costs of capital.

In the figure there are two industries, industrial machinery and electonics, that appear somewhat inconsistent with the generally negative relation we observe between GDP betas and the sensitivity to $\mathrm{E}_{t-1}\left[R B R F_{t}\right]$. It is notable that both of these industries are characterized by a very high rate of technological innovation, as proxied by the ratio of patents to shipments, meaning that inventories held by firms in these industries may quickly become obsolete. Furthermore, both of these industries have long delivery lead times, implying a lack of flexibility in adjusting those inventories. Together, these factors should amplify the effects of a shock to business conditions on the value of inventories, suggesting that our beta measure may be inadequate for capturing the true riskiness of inventory investment in these industries.

\section{Conclusion}

We believe that our results demonstrate conclusively that inventory investment is affected by time variation in the cost of capital. Unlike other work, which focuses only on variation in the real interest rate, we identify fluctuating risk premia as a significant source of time-varying inventory growth. As in most of the prior literature, we find no relation between real interest rates and inventory growth.

Our results are robust to a number of different specifications of the risk premium and to an alternative method for selecting instruments for our IV regressions. We find significant effects both for input and output inventories, and the results are generally insensitive to detrending the ratio of inventories to sales.

We develop a theoretical model that in calibration suggests that inventory investment might be as risky as investment in fixed capital, if not more so. The relative betas of the two types of investment are determined by the costliness of adjusting fixed capital and the higher depreciation of inventories. Adjustment costs make fixed capital more risky as firms are unable to respond freely to surprises in productivity. But a second effect arising from the higher depreciation rate of inventories works in the opposite direction, making inventory investment relatively risky. Intuitively, higher depreciation makes either form of investment riskier because it makes payoffs depend on short-term productivity instead of smoother long-term averages.

Empirically, we find suggestive evidence that higher risk inventories are more sensitive to movements in risk premia. Our model implies that more durable inventories are riskier, and in the data we find that expenditures on durable goods are 2.5 times more sensitive to GDP growth than nondurables. Consistent with this view we find that durable inventory growth is much more sensitive to time varying risk premia than is growth in nondurables.

We also find that industries, like transportation equipment and primary metals, that are more sensitive 
to the business cycle are also more sensitive to risk premia relative to industries that are not, like food and tobacco. While the small number of industries in our sample has made a formal statistical test of this relation difficult, we believe that the result is striking enough to merit further investigation.

Our study does not answer the puzzle as to why real interest rates appear unrelated to the inventory investment decision. One possibility is simply a lack of power in our statistical tests - real rates exhibit little variation relative to our proxies for bond and stock risk premia, and it is possible that real rates are simply too smooth to exert a detectible effect on inventory growth rates. Alternatively, financial constraints such as those studied by Kashyap, Stein, and Wilcox (1993) might make the real rate an unreliable proxy even for the cost of short-term borrowing. We believe that our paper makes these issues no less interesting.

\section{A Data appendix}

For deflating our aggregate nominal inventories and shipments data, we either use the PPI for manufactured goods, durable manufactured goods, or nondurable manufactured goods depending on the type of good. For industries, we use the PPI series suggested by Roberts, Stockton, and Struckmeyer (1994) In several cases, when PPI data are only available for subsectors of a given industry, we follow their approach and aggregate the subsector-level series into an industry-level series by taking shipments-based weighted averages. In all cases, PPI data are not seasonally adjusted, so we seasonally adjusted them using the U.S. Census' X12a program.

In the M3 database, most data series are available monthly from January 1958 until the end of our sample in December 2006. Prior to 1992, industry classifications are based on the Standard Industrial Classification (SIC) codes. Between January 1992 and March 2001, both SIC and NAICS (North American Industry Classification) codes are used, but after March 2001 the database includes only NAICS codes. Data for broad categories such as manufacturing, durables and nondurables are labeled the same way both based on SIC and NAICS codes. For industry-level data, we match SIC and NAICS codes using the "Dispersement of M3 SIC Categories" and "Origination of M3 NAICS Categories" files from the M3 website. We consider SIC- and NAICS-based industries "matched" if more than $90 \%$ of the SIC industry is dispersed into a given NAICS industry for which data are available and more than $90 \%$ of the NAICS industry originates with that same SIC industry. In some cases, one SIC industry is dispersed into multiple NAICS industries in such a way that the NAICS industries combined meet our criteria for inclusion, which we then splice onto the single SIC industry.

Though the levels of inventory and shipments data differ between SIC-based and NAICS-based industries, 
their growth rates are quite similar over the 1992-2001 period when both classifications were used. We therefore use data reported based on SIC codes until March 2001 and then extend the series by splicing NAICS-based growth rates starting in April 2001.

Table A1 summarizes the data series used. Industry name is from the SIC classifications. SIC denotes the code used in the M3 database to denote that SIC-based industry. NAICS is the code used in the M3 database to describe a NAICS-based industry. Deflator code and PPI Series are the code and name, respectively, used by the Bureau of Labor Statistics to describe the PPI series that we use to deflate the corresponding shipments and inventories data. 


\section{References}

Ang, Andrew, Monika Piazzesi, and Min Wei, "What Does the Yield Curve Tell us about GDP Growth?" Journal of Econometrics 131, 359-403.

Blackstone, John H., Jr., and James Cox III, 2007, APICS Dictionary, American Production and Inventory Control Society.

Boldrin, Michele, Lawrence Christiano, and Jonas Fisher, 2001, "Habit Persistence, Asset Returns, and the Business Cycle," American Economic Review 91, 149-166.

Campbell, John, and Robert Shiller, 1991, "Yield Spreads and Interest Rate Movements: A Bird's Eye View," Review of Economic Studies 58, 495-514.

Carpenter, Robert, Steven M. Fazzari, and Bruce C. Petersen, 1994, "Inventory Investment, Internal-Finance Fluctuation, and the Business Cycle," Brookings Papers on Economic Activity 25, 75-138.

Chirinko, Robert S., 1993, "Multiple Capital Inputs, q, and Investment Spending," Journal of Economic Dynamics and Control 17, 907-928.

Christiano, Lawrence J., 1988, "Why Does Inventory Investment Fluctuate so Much?" Journal of Monetary Economics 21, 247-280.

Cochrane, John, and Monika Piazzesi, 2005, "Bond Risk Premia," American Economic Review 95, 138-160.

Cooley, Thomas F., and Edward C. Prescott, 1995, "Economic Growth and Business Cycles," Frontiers of Business Cycle Research, (Thomas F. Cooley, editor), Princeton University Press.

Council of Supply Chain Management Professionals, 2008, Annual State of Logistics Report, http://cscmp.org/downloads/public/memberonly/sol-executivesummary.pdf.

Fama, Eugene, 1975, "Short-Term Interest Rates as Predictors of Inflation," American Economic Review 65, 269-282.

Fama, Eugene, and Robert Bliss, 1987, "The Information in Long-Maturity Forward Rates," American Economic Review 77, 680-692.

Fama, Eugene, and Kenneth French, 1989, "Business Conditions and Expected Returns on Stocks and Bonds," Journal of Financial Economics 25, 23-49.

Gertler, Mark, and Simon Gilchrist, 1994, "Monetary Policy, Business Cycles, and the Behavior of Small Manufacturing Firms," Quarterly Journal of Economics 109, 309-340.

Harvey, Campbell R., 1988, "The Real Term Structure and Consumption Growth," Journal of Financial Economics 22, 305-333.

Brad Humphreys, Maccini, Louis, and Scott Schuh, 2001, "Input and Output Inventories, " Journal of Monetary Economics 47, 347-375. 
Kashyap, Anil, Owen A. Lamont, and Jeremy C. Stein, 1994, "Credit Conditions and the Cyclical Behavior of Inventories," Quarterly Journal of Economics 109, 565-592.

Kashyap, Anil, Jeremy C. Stein, and David W. Wilcox, 1993, "Monetary Policy and Credit Conditions: Evidence from the Composition of External Finance," American Economic Review 83, 78-98.

Keim, Donald, and Robert Stambaugh, 1986, "Predicting Returns in the Stock and Bond Markets," Journal of Financial Economics 17, 357-390.

Kydland, Finn, and Edward Prescott, 1982, "Time to Build and Aggregate Fluctuations," Econometrica 50, 1345-1370.

Lettau, Martin, and Sydney Ludvigson, 2001, "Consumption, Aggregate Wealth, and Expected Stock Returns," Journal of Finance 56, 815-849.

Lord, Dennis, 2008, "The Real Cost of Carrying Inventory," www.imsconsulting.ca.

Lovell, Michael, 1961, "Manufacturers' Inventories, Sales Expectations, and the Acceleration Principle," Econometrica 29, 293-314.

Maccini, Louis, Bartholomew Moore, and Huntley Schaller, 2004, "The Interest Rate, Learning, and Inventory Investment," American Economic Review 94, 1303-1327.

Nelson, Charles and G. William Schwert, 1977, "Short-Term Interest Rates as Predictors of Inflation: On Testing the Hypothesis that the Real Rate of Interest is Constant," American Economic Review 67, $478-486$.

Newey, Whitney, and Kenneth West, 1987, "A Simple, Positive Semi-definite, Heteroskedasticity and Autocorrelation Consistent Covariance Matrix," Econometrica 55, 703-708.

Pagan, Adrian, 1984, "Econometric Issues In The Analysis Of Regressions With Generated Regressors," International Economic Review 25, 221-247.

Richardson, Helen, 1995, "Control Your Costs Then Cut Them," Transportation and Distribution, 94-96.

Roberts, John, David Stockton, and Charles Struckmeyer, 1994, "Evidence on the Flexibility of Prices," Review of Economics and Statistics 76, 142-150.

Shiller, Robert, 2000, Irrational Exuberance, Princeton University Press.

Timme, Stephen, and Christine Williams-Timme, 2003, "The Real Cost of Holding Inventory," Supply Chain Management Review 7, 30-37 .

U.S. Patent and Trademark Office, 1999, Patenting Trends in the United States: State Country Report, 1963-1998.

Yogo, Motohiro, 2006, "A Consumption-Based Explanation of Expected Stock Returns," Journal of Finance $61,539-580$. 


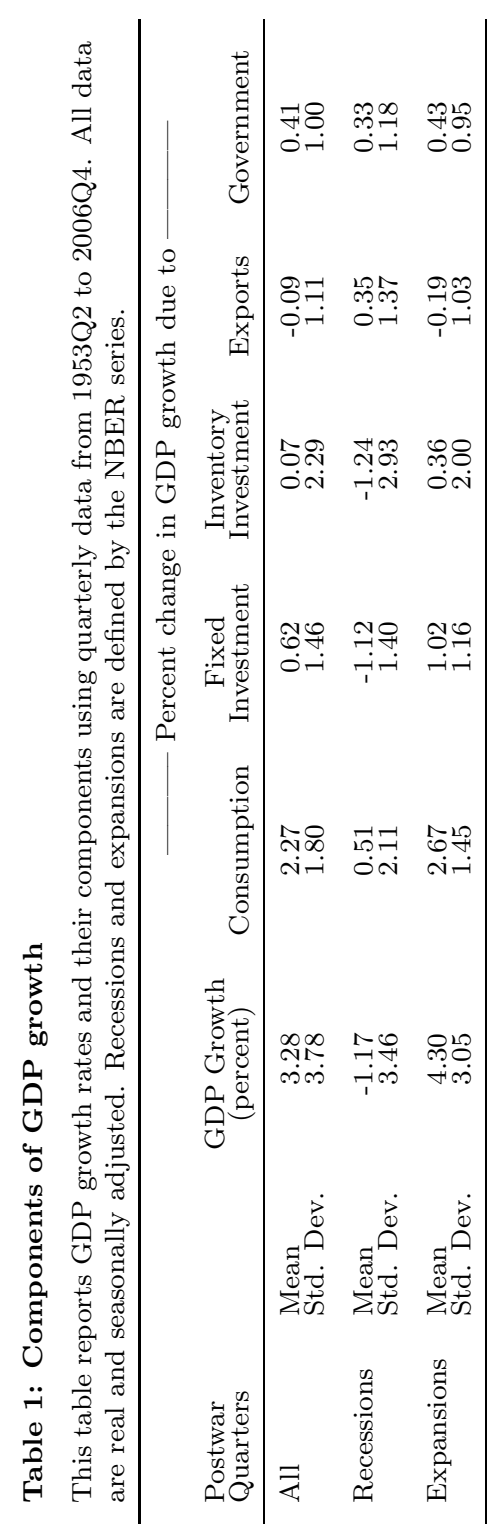




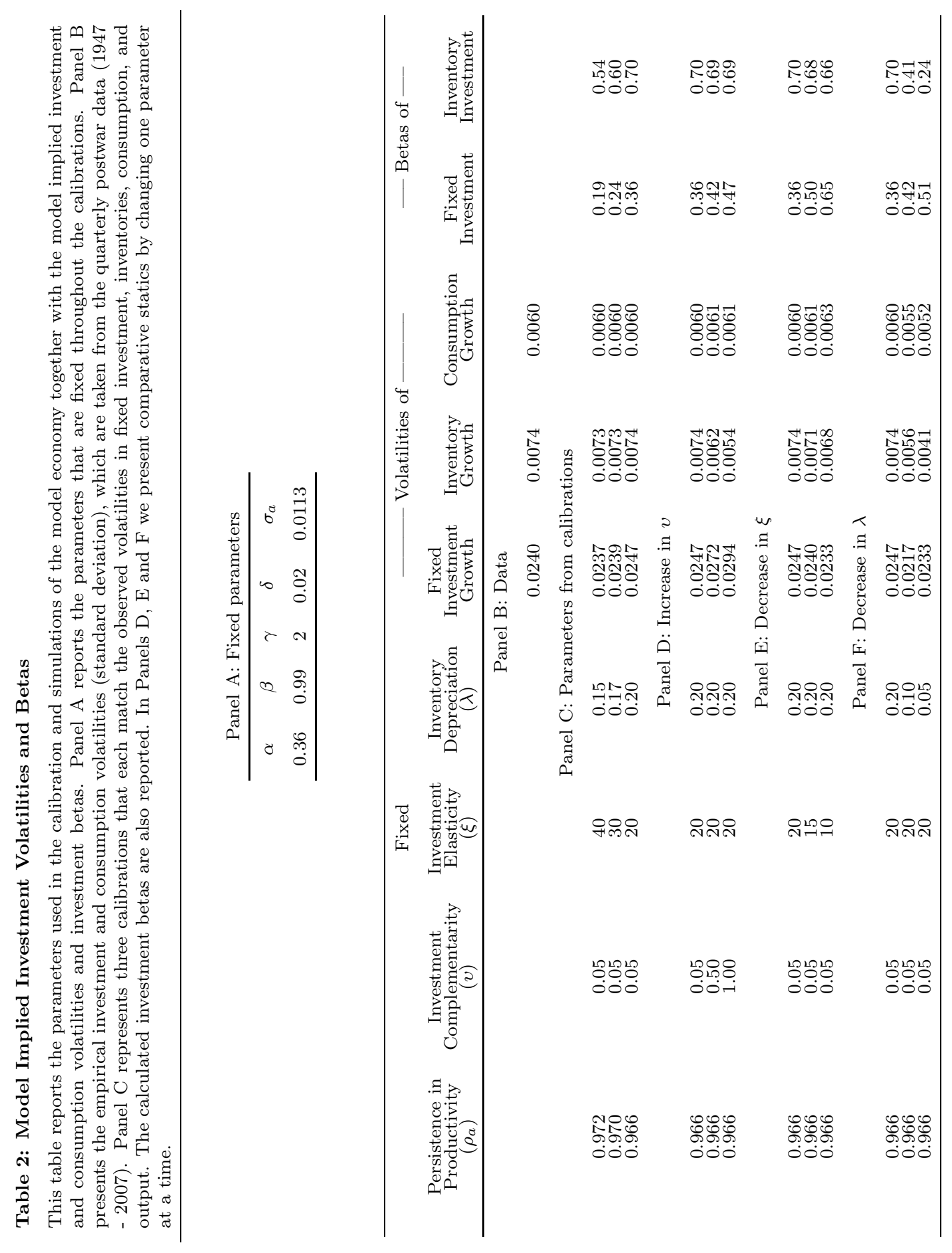




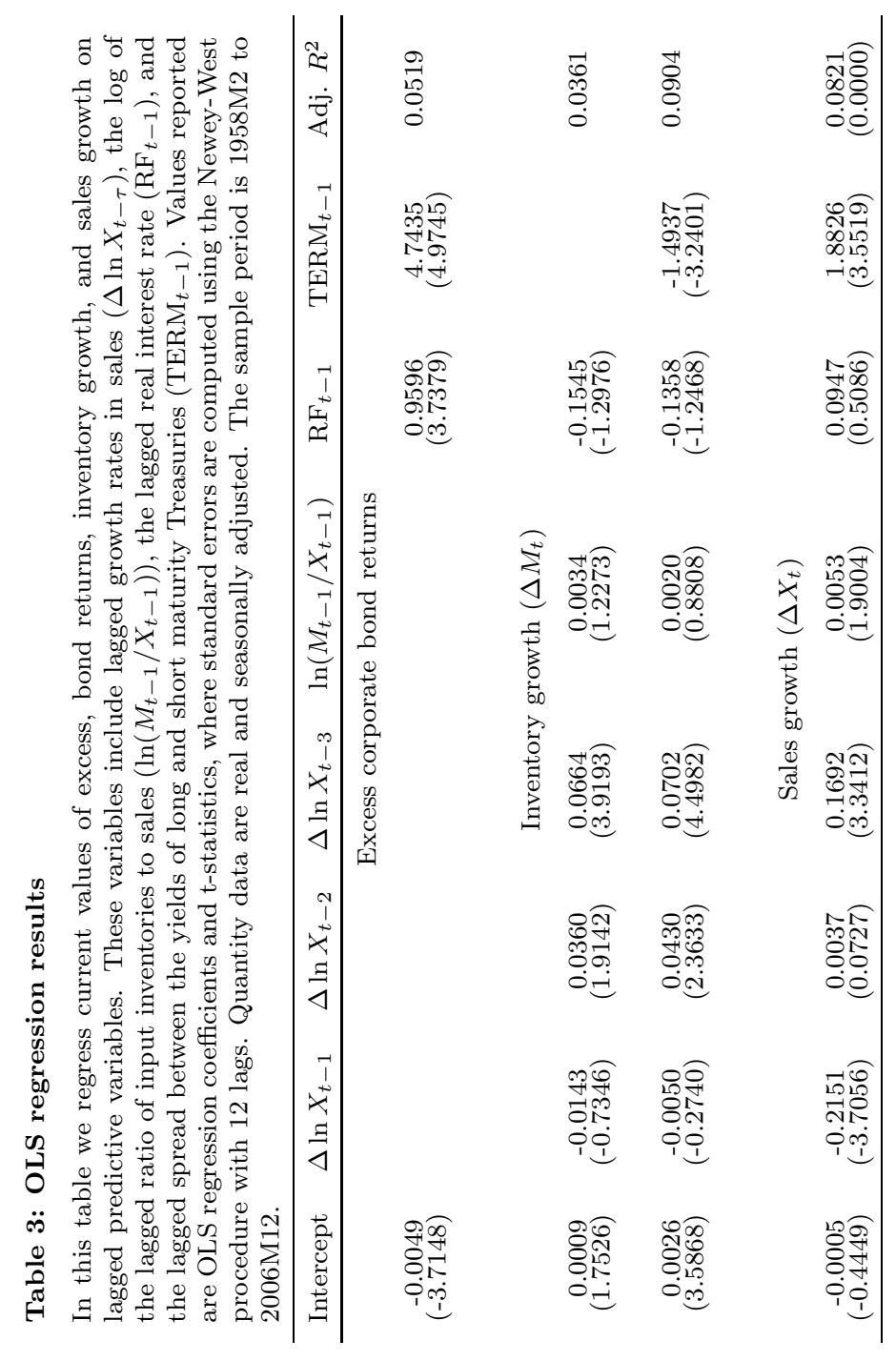




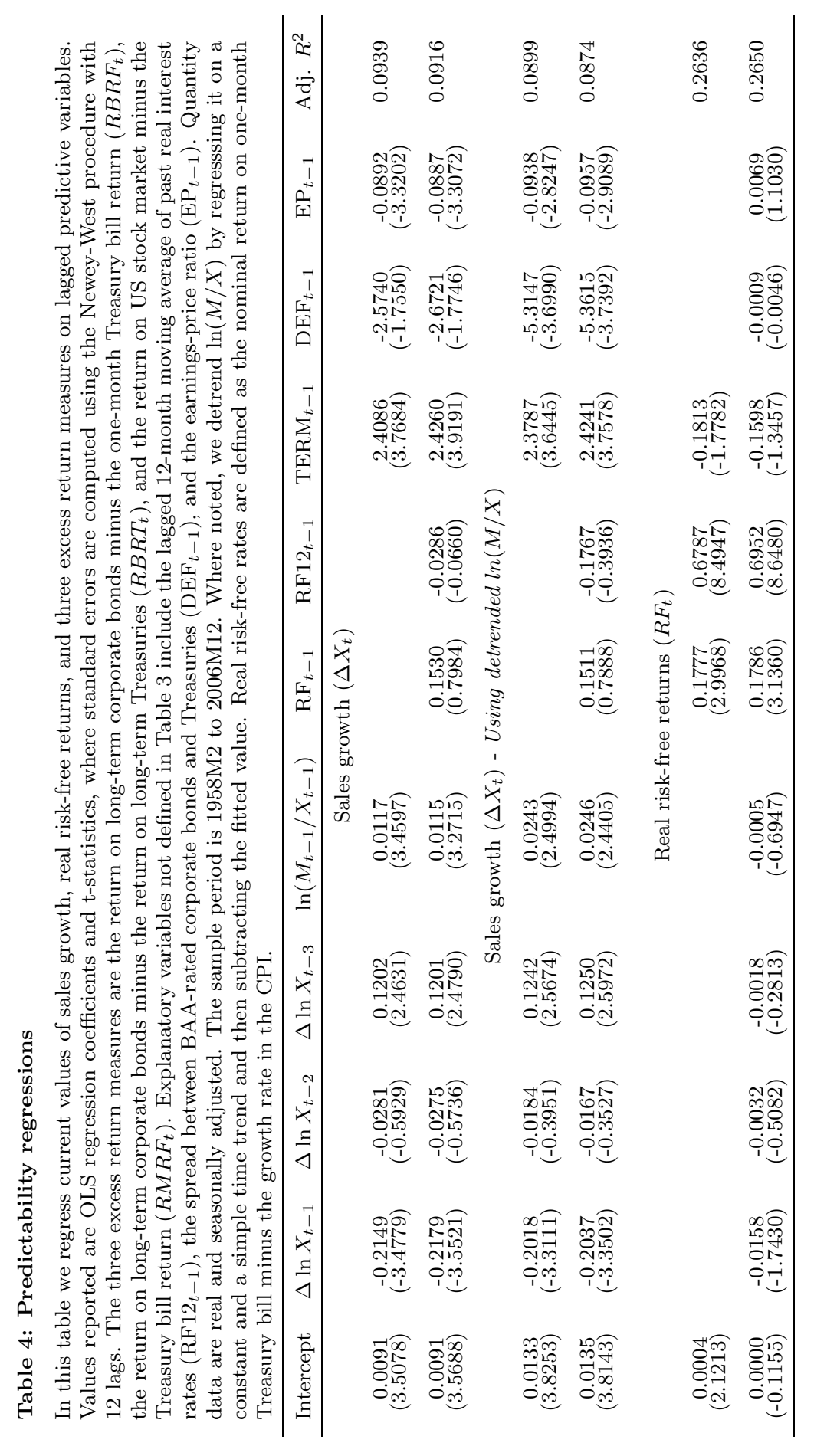




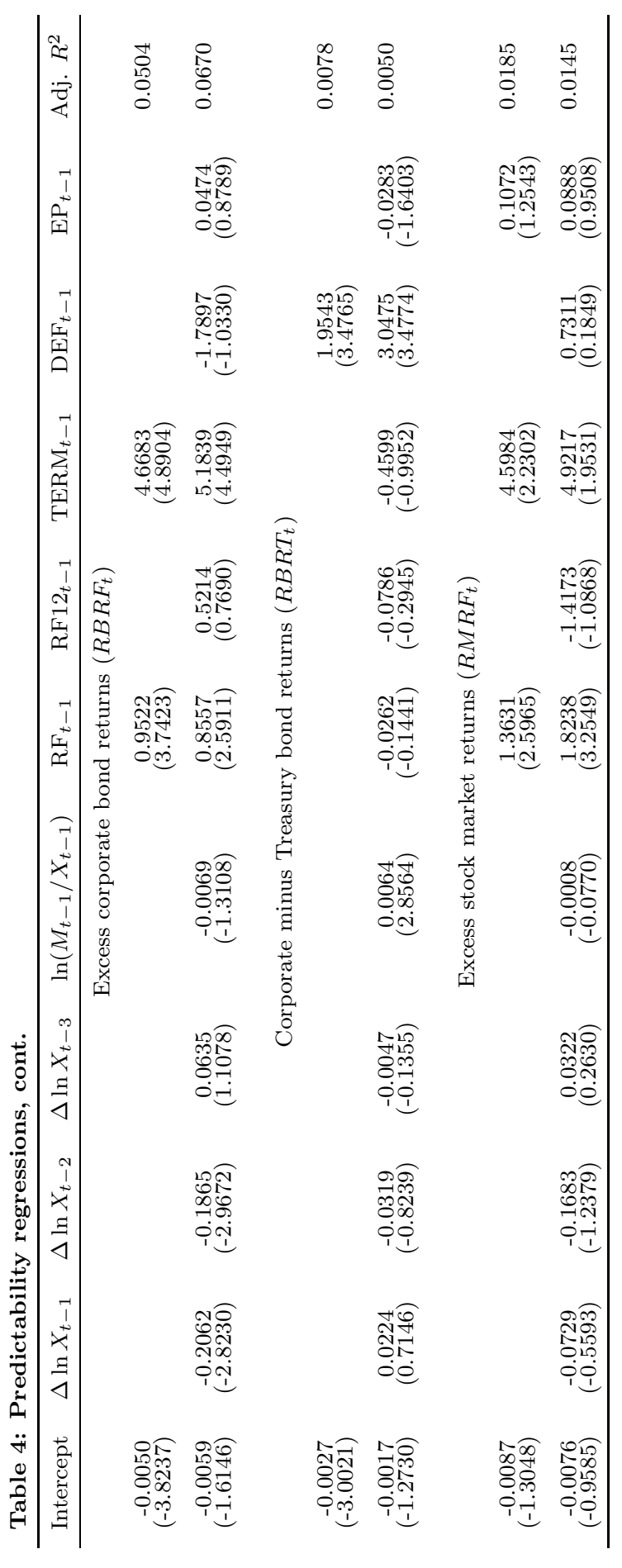


Table 5: Manufacturing input inventory growth regressions

In this table we perform instrumental variables regressions of manufacturing input inventory growth rates on an inventory stock measure, expected sales growth, the real riskless interest rate, and a risk premia measure. Values reported are 2SLS regression coefficients and t-statistics. All variables are defined in Tables 3 and 4 , and first-stage regressions for each variable are in Table 4 . In Panel A, we use separate instruments for each explanatory variable. These use the restricted first-stage regressions in Table 4. Standard errors for these results are computed using the method of Pagan (1984) with a Newey-West adjustment with 12 lags. In Panel B, all instruments are used. These are the unrestricted regressions from Table 4. Standard errors here use a standard IV/Newey-West approach with 12 lags. All quantity data are real and seasonally adjusted, and the sample period is $1958 \mathrm{M} 2$ to $2006 \mathrm{M} 12$. Where noted, we detrend $\ln (M / X)$ by regresssing it on a constant and a simple time trend and then subtracting the fitted value.

\begin{tabular}{lllllll}
\hline Intercept & $\ln \left(M_{t-1} / X_{t-1}\right)$ & $\mathrm{E}\left[\Delta \ln X_{t}\right]$ & $\mathrm{E}\left[\mathrm{RF}_{t}\right]$ & $\mathrm{E}\left[\mathrm{RBRF}_{t}\right]$ & $\mathrm{E}\left[\mathrm{RBRT}_{t}\right]$ & $\mathrm{E}\left[\mathrm{RMRF}_{t}\right]$ \\
\hline
\end{tabular}

Panel A: Equation-specific instruments

\begin{tabular}{|c|c|c|c|c|c|c|}
\hline \multicolumn{7}{|c|}{ No detrending } \\
\hline $\begin{array}{c}0.0006 \\
(0.7057)\end{array}$ & $\begin{array}{c}0.0007 \\
(0.2079)\end{array}$ & $\begin{array}{c}0.2572 \\
(1.6190)\end{array}$ & $\begin{array}{c}0.4157 \\
(1.0222)\end{array}$ & $\begin{array}{c}-0.3756 \\
(-3.2763)\end{array}$ & & \\
\hline $\begin{array}{r}0.0013 \\
(1.5918)\end{array}$ & $\begin{array}{l}-0.0006 \\
(-0.1621)\end{array}$ & $\begin{array}{c}0.0322 \\
(0.1998)\end{array}$ & $\begin{array}{c}-0.0114 \\
(-0.0296)\end{array}$ & & $\begin{array}{c}-2.3425 \\
(-7.2088)\end{array}$ & \\
\hline $\begin{array}{c}0.0017 \\
(2.4284)\end{array}$ & $\begin{array}{c}0.0039 \\
(1.1185)\end{array}$ & $\begin{array}{c}0.1481 \\
(1.3582)\end{array}$ & $\begin{array}{c}0.3729 \\
(1.1235)\end{array}$ & & & $\begin{array}{c}-0.2695 \\
(-3.5854)\end{array}$ \\
\hline \multicolumn{7}{|c|}{ Detrended $\ln (M / X)$} \\
\hline $\begin{array}{r}0.0005 \\
(0.6247)\end{array}$ & $\begin{array}{l}-0.0104 \\
(-2.0011)\end{array}$ & $\begin{array}{c}0.2582 \\
(1.9836)\end{array}$ & $\begin{array}{c}0.4663 \\
(1.1961)\end{array}$ & $\begin{array}{c}-0.3596 \\
(-3.7118)\end{array}$ & & \\
\hline $\begin{array}{r}0.0013 \\
(1.2907)\end{array}$ & $\begin{array}{l}-0.0021 \\
(-0.2875)\end{array}$ & $\begin{array}{c}0.0229 \\
(0.0925)\end{array}$ & $\begin{array}{c}0.0007 \\
(0.0016)\end{array}$ & & $\begin{array}{l}-2.2511 \\
(-3.0657)\end{array}$ & \\
\hline $\begin{array}{c}0.0013 \\
(2.4295)\end{array}$ & $\begin{array}{l}-0.0071 \\
(-1.4051)\end{array}$ & $\begin{array}{c}0.1760 \\
(1.9810)\end{array}$ & $\begin{array}{c}0.3015 \\
(1.0478)\end{array}$ & & & $\begin{array}{l}-0.2059 \\
(-2.9604)\end{array}$ \\
\hline
\end{tabular}

Panel B: All instruments used

\begin{tabular}{|c|c|c|c|c|c|c|}
\hline \multicolumn{7}{|c|}{ No detrending } \\
\hline $\begin{array}{r}0.0003 \\
(0.3998)\end{array}$ & $\begin{array}{c}-0.0005 \\
(-0.1613)\end{array}$ & $\begin{array}{c}0.3716 \\
(2.3389)\end{array}$ & $\begin{array}{c}0.3455 \\
(0.8496)\end{array}$ & $\begin{array}{c}-0.3283 \\
(-2.8634)\end{array}$ & & \\
\hline $\begin{array}{r}0.0015 \\
(1.8261)\end{array}$ & $\begin{array}{c}0.0066 \\
(1.9051)\end{array}$ & $\begin{array}{c}0.0007 \\
(0.0046)\end{array}$ & $\begin{array}{c}-0.1998 \\
(-0.5169)\end{array}$ & & $\begin{array}{l}-1.4075 \\
(-4.3313)\end{array}$ & \\
\hline $\begin{array}{r}0.0017 \\
(2.4703)\end{array}$ & $\begin{array}{c}0.0029 \\
(0.8310)\end{array}$ & $\begin{array}{c}0.1840 \\
(1.6879)\end{array}$ & $\begin{array}{c}0.0614 \\
(0.1851)\end{array}$ & & & $\begin{array}{c}-0.2271 \\
(-3.0209)\end{array}$ \\
\hline \multicolumn{7}{|c|}{ Detrended $\ln (M / X)$} \\
\hline $\begin{array}{r}0.0003 \\
(0.3325)\end{array}$ & $\begin{array}{l}-0.0115 \\
(-2.2109)\end{array}$ & $\begin{array}{c}0.3319 \\
(2.5498)\end{array}$ & $\begin{array}{c}0.4257 \\
(1.0920)\end{array}$ & $\begin{array}{l}-0.2848 \\
(-2.9397)\end{array}$ & & \\
\hline $\begin{array}{r}0.0015 \\
(1.4708)\end{array}$ & $\begin{array}{l}-0.0091 \\
(-1.2411)\end{array}$ & $\begin{array}{c}-0.1622 \\
(-0.6560)\end{array}$ & $\begin{array}{c}0.0677 \\
(0.1474)\end{array}$ & & $\begin{array}{l}-1.6952 \\
(-2.3087)\end{array}$ & \\
\hline $\begin{array}{c}0.0012 \\
(2.3264)\end{array}$ & $\begin{array}{l}-0.0111 \\
(-2.1915)\end{array}$ & $\begin{array}{c}0.1589 \\
(1.7876)\end{array}$ & $\begin{array}{c}0.1349 \\
(0.4688)\end{array}$ & & & $\begin{array}{l}-0.1540 \\
(-2.2136)\end{array}$ \\
\hline
\end{tabular}


Table 6: Manufacturing output inventory growth regressions

In this table we perform instrumental variables regressions of manufacturing output inventory growth rates on an inventory stock measure, expected sales growth, the real riskless interest rate, and a risk premia measure. Values reported are 2SLS regression coefficients and t-statistics. The regressions in table are identical to those in Table 5 except that they examines output rather than input inventories. The same regressors are used except that we now use the the log of the lagged ratio of output inventories to sales $\left(\ln \left(N_{t-1} / X_{t-1}\right)\right)$ in place of the corresoinding measure for input inventories.

\begin{tabular}{|c|c|c|c|c|c|c|}
\hline Intercept & $\ln \left(N_{t-1} / X_{t-1}\right)$ & $\mathrm{E}\left[\Delta \ln X_{t}\right]$ & $\mathrm{E}\left[\mathrm{RF}_{t}\right]$ & $\mathrm{E}\left[\mathrm{RBRF}_{t}\right]$ & $\mathrm{E}\left[\mathrm{RBRT}_{t}\right]$ & $\mathrm{E}\left[\mathrm{RMRF}_{t}\right]$ \\
\hline \multicolumn{7}{|c|}{ Panel A: Equation-specific instruments } \\
\hline \multicolumn{7}{|c|}{ No detrending } \\
\hline $\begin{array}{c}-0.0001 \\
(-0.0265)\end{array}$ & $\begin{array}{l}-0.0012 \\
(-0.2982)\end{array}$ & $\begin{array}{c}0.1823 \\
(1.1694)\end{array}$ & $\begin{array}{c}0.5041 \\
(1.1708)\end{array}$ & $\begin{array}{l}-0.2936 \\
(-2.9888)\end{array}$ & & \\
\hline $\begin{array}{c}0.0000 \\
(0.0119)\end{array}$ & $\begin{array}{l}-0.0019 \\
(-0.4847)\end{array}$ & $\begin{array}{c}0.0186 \\
(0.1572)\end{array}$ & $\begin{array}{c}0.1303 \\
(0.4388)\end{array}$ & & $\begin{array}{c}-1.5385 \\
(-5.1383)\end{array}$ & \\
\hline $\begin{array}{c}0.0027 \\
(0.9294)\end{array}$ & $\begin{array}{c}0.0015 \\
(0.3995)\end{array}$ & $\begin{array}{c}0.0893 \\
(0.8172)\end{array}$ & $\begin{array}{c}0.4296 \\
(1.3055)\end{array}$ & & & $\begin{array}{l}-0.1887 \\
(-2.6724)\end{array}$ \\
\hline \multicolumn{7}{|c|}{ Detrended $\ln (N / X)$} \\
\hline $\begin{array}{c}0.0008 \\
(0.9743)\end{array}$ & $\begin{array}{l}-0.0206 \\
(-2.0875)\end{array}$ & $\begin{array}{c}0.1704 \\
(1.3067)\end{array}$ & $\begin{array}{c}0.4670 \\
(1.1955)\end{array}$ & $\begin{array}{c}-0.2294 \\
(-2.5302)\end{array}$ & & \\
\hline $\begin{array}{c}0.0013 \\
(1.7647)\end{array}$ & $\begin{array}{l}-0.0095 \\
(-0.5795)\end{array}$ & $\begin{array}{c}0.0073 \\
(0.0441)\end{array}$ & $\begin{array}{c}0.1491 \\
(0.4864)\end{array}$ & & $\begin{array}{l}-1.2249 \\
(-1.6948)\end{array}$ & \\
\hline $\begin{array}{c}0.0013 \\
(2.0539)\end{array}$ & $\begin{array}{l}-0.0204 \\
(-2.2186)\end{array}$ & $\begin{array}{c}0.1198 \\
(1.2776)\end{array}$ & $\begin{array}{c}0.3636 \\
(1.2229)\end{array}$ & & & $\begin{array}{l}-0.1253 \\
(-2.0290)\end{array}$ \\
\hline \multicolumn{7}{|c|}{ Panel B: All instruments used } \\
\hline \multicolumn{7}{|c|}{ No detrending } \\
\hline $\begin{array}{r}-0.0005 \\
(-0.1596)\end{array}$ & $\begin{array}{l}-0.0016 \\
(-0.3922)\end{array}$ & $\begin{array}{c}0.2554 \\
(1.6383)\end{array}$ & $\begin{array}{c}0.4218 \\
(0.9796)\end{array}$ & $\begin{array}{l}-0.2221 \\
(-2.2610)\end{array}$ & & \\
\hline $\begin{array}{c}0.0065 \\
(2.2390)\end{array}$ & $\begin{array}{c}0.0072 \\
(1.8765)\end{array}$ & $\begin{array}{l}-0.0357 \\
(-0.3022)\end{array}$ & $\begin{array}{c}0.1244 \\
(0.4193)\end{array}$ & & $\begin{array}{l}-0.9317 \\
(-3.1117)\end{array}$ & \\
\hline $\begin{array}{c}0.0030 \\
(1.0627)\end{array}$ & $\begin{array}{c}0.0020 \\
(0.5441)\end{array}$ & $\begin{array}{c}0.1169 \\
(1.0697)\end{array}$ & $\begin{array}{c}0.2696 \\
(0.8193)\end{array}$ & & & $\begin{array}{l}-0.1640 \\
(-2.3227)\end{array}$ \\
\hline \multicolumn{7}{|c|}{ Detrended $\ln (N / X)$} \\
\hline $\begin{array}{c}0.0006 \\
(0.7899)\end{array}$ & $\begin{array}{l}-0.0209 \\
(-2.1181)\end{array}$ & $\begin{array}{c}0.2093 \\
(1.6046)\end{array}$ & $\begin{array}{c}0.4038 \\
(1.0336)\end{array}$ & $\begin{array}{l}-0.1448 \\
(-1.5973)\end{array}$ & & \\
\hline $\begin{array}{c}0.0014 \\
(1.8880)\end{array}$ & $\begin{array}{l}-0.0017 \\
(-0.1030)\end{array}$ & $\begin{array}{l}-0.0507 \\
(-0.3086)\end{array}$ & $\begin{array}{c}0.1444 \\
(0.4711)\end{array}$ & & $\begin{array}{l}-1.0818 \\
(-1.4967)\end{array}$ & \\
\hline $\begin{array}{c}0.0012 \\
(1.9281)\end{array}$ & $\begin{array}{l}-0.0196 \\
(-2.1375)\end{array}$ & $\begin{array}{c}0.1300 \\
(1.3857)\end{array}$ & $\begin{array}{c}0.2807 \\
(0.9441)\end{array}$ & & & $\begin{array}{l}-0.0970 \\
(-1.5715)\end{array}$ \\
\hline
\end{tabular}


Table 7: Manufacturing input inventory growth regressions

In this table we perform instrumental variables regressions of durable and nondurable manufacturing output inventory growth rates on an inventory stock measure, expected sales growth, the real riskless interest rate, and a risk premia measure. Values reported are 2SLS regression coefficients and t-statistics. The regressions in table are identical to those in Table 5 except that we now separate durables from non-durables. This changes the dependent variable and also the measure of input inventories used to construct one independent variable, the ratio of inventories to shipments $\left(\ln \left(M_{t-1} / X_{t-1}\right)\right)$. Results for all manufacturing goods are repeated from Table 5 for convenience.

\begin{tabular}{llllll}
\hline Intercept & $\ln \left(M_{t-1} / X_{t-1}\right)$ & $\mathrm{E}\left[\Delta \ln X_{t}\right]$ & $\mathrm{E}\left[\mathrm{RF}_{t}\right]$ & $\mathrm{E}\left[\mathrm{RBRF}_{t}\right]$ \\
\hline
\end{tabular}

Panel A: Equation-specific instruments

\begin{tabular}{lccccc} 
& \multicolumn{5}{c}{ No detrending } \\
All manufacturing & 0.0006 & 0.0007 & 0.2572 & 0.4157 & -0.3756 \\
& $(0.7057)$ & $(0.2079)$ & $(1.6190)$ & $(1.0222)$ & $(-3.2763)$ \\
Durables only & 0.0014 & -0.0015 & 0.1648 & 0.5011 & -0.4862 \\
& $(1.2524)$ & $(-0.4455)$ & $(1.1177)$ & $(0.9564)$ & $(-3.4010)$ \\
Non-durables only & 0.0015 & 0.0022 & 0.2054 & 0.0744 & -0.1307 \\
& $(1.0967)$ & $(0.8389)$ & $(1.6601)$ & $(0.2617)$ & $(-1.4595)$ \\
& & & & \\
All manufacturing & 0.0005 & -0.0104 & 0.2582 & 0.4663 & -0.3596 \\
& $(0.6247)$ & $(-2.0011)$ & $(1.9836)$ & $(1.1961)$ & $(-3.7118)$ \\
Durables only & 0.0009 & -0.0105 & 0.1377 & 0.5503 & -0.4270 \\
& $(1.0066)$ & $(-2.4949)$ & $(1.1664)$ & $(1.1806)$ & $(-3.6784)$ \\
Non-durables only & 0.0005 & -0.0335 & 0.2271 & 0.0805 & -0.1589 \\
& $(0.8315)$ & $(-2.7591)$ & $(2.1604)$ & $(0.2544)$ & $(-2.0439)$
\end{tabular}

Panel B: All instruments used

\begin{tabular}{lccccc} 
& \multicolumn{5}{c}{ No detrending } \\
All manufacturing & 0.0003 & -0.0005 & 0.3716 & 0.3455 & -0.3283 \\
& $(0.3998)$ & $(-0.1613)$ & $(2.3389)$ & $(0.8496)$ & $(-2.8634)$ \\
Durables only & 0.0014 & -0.0030 & 0.2695 & 0.5415 & -0.4509 \\
\multirow{2}{*}{ Non-durables only } & $(1.2956)$ & $(-0.8713)$ & $(1.8273)$ & $(1.0336)$ & $(-3.1541)$ \\
& 0.0016 & 0.0021 & 0.2184 & -0.1129 & -0.0859 \\
& $(1.1386)$ & $(0.8004)$ & $(1.7649)$ & $(-0.3969)$ & $(-0.9590)$
\end{tabular}

Detrended $\ln (M / X)$

\begin{tabular}{lccccc} 
All manufacturing & 0.0003 & -0.0115 & 0.3319 & 0.4257 & -0.2848 \\
& $(0.3325)$ & $(-2.2109)$ & $(2.5498)$ & $(1.0920)$ & $(-2.9397)$ \\
Durables only & 0.0006 & -0.0119 & 0.1992 & 0.5785 & -0.3612 \\
& $(0.6912)$ & $(-2.8223)$ & $(1.6867)$ & $(1.2411)$ & $(-3.1116)$ \\
Non-durables only & 0.0005 & -0.0318 & 0.2452 & -0.0960 & -0.0977 \\
& $(0.9432)$ & $(-2.6194)$ & $(2.3324)$ & $(-0.3035)$ & $(-1.2567)$ \\
\hline
\end{tabular}


Table 8: Manufacturing output inventory growth regressions

In this table we perform instrumental variables regressions of durable and nondurable manufacturing input inventory growth rates on an inventory stock measure, expected sales growth, the real riskless interest rate, and a risk premia measure. Values reported are 2SLS regression coefficients and t-statistics. The regressions in table are identical to those in Table 7 except that we examine input rather than output inventories.

\begin{tabular}{lllll}
\hline Intercept & $\ln \left(N_{t-1}\right)-\ln \left(X_{t-1}\right)$ & $\mathrm{E}\left[\Delta \ln X_{t}\right]$ & $\mathrm{E}\left[\mathrm{RF}_{t}\right]$ & $\mathrm{E}\left[\mathrm{RBRF}_{t}\right]$ \\
\hline
\end{tabular}

Panel A: Equation-specific instruments

\begin{tabular}{lccccc}
\multicolumn{5}{c}{ No detrending } \\
All manufacturing & -0.0001 & -0.0012 & 0.1823 & 0.5041 & -0.2936 \\
& $(-0.0265)$ & $(-0.2982)$ & $(1.1694)$ & $(1.1708)$ & $(-2.9888)$ \\
Durables only & -0.0036 & -0.0063 & 0.1429 & 0.5831 & -0.3631 \\
& $(-0.8072)$ & $(-1.1855)$ & $(0.8878)$ & $(0.9569)$ & $(-2.4694)$ \\
Non-durables only & 0.0018 & 0.0017 & 0.1576 & 0.4069 & -0.1847 \\
& $(0.6904)$ & $(0.4932)$ & $(1.1914)$ & $(1.1938)$ & $(-1.9795)$ \\
& & & & \\
All manufacturing & 0.0008 & Detrended $\ln (N / X)$ & & \\
& $(0.9743)$ & $(-2.0875)$ & $(1.3067)$ & $(1.1955)$ & $(-2.5302)$ \\
Durables only & 0.0012 & -0.0219 & 0.0397 & 0.4767 & -0.2068 \\
& $(1.5131)$ & $(-3.3531)$ & $(0.3942)$ & $(1.0162)$ & $(-1.8774)$ \\
Non-durables only & 0.0005 & -0.0131 & 0.1935 & 0.4464 & -0.2044 \\
& $(0.7636)$ & $(-1.6904)$ & $(1.4998)$ & $(1.2812)$ & $(-2.2772)$
\end{tabular}

Panel B: All instruments used

\begin{tabular}{lccccc} 
& \multicolumn{5}{c}{ No detrending } \\
All manufacturing & -0.0005 & -0.0016 & 0.2554 & 0.4218 & -0.2221 \\
& $(-0.1596)$ & $(-0.3922)$ & $(1.6383)$ & $(0.9796)$ & $(-2.2610)$ \\
Durables only & -0.0045 & -0.0072 & 0.2198 & 0.5831 & -0.3157 \\
& $(-1.0104)$ & $(-1.3502)$ & $(1.3656)$ & $(0.9570)$ & $(-2.1473)$ \\
Non-durables only & 0.0027 & 0.0031 & 0.1267 & 0.2643 & -0.0699 \\
& $(1.0589)$ & $(0.8844)$ & $(0.9572)$ & $(0.7754)$ & $(-0.7491)$
\end{tabular}

Detrended $\ln (N / X)$

\begin{tabular}{lccccc} 
All manufacturing & 0.0006 & -0.0209 & 0.2093 & 0.4038 & -0.1448 \\
& $(0.7899)$ & $(-2.1181)$ & $(1.6046)$ & $(1.0336)$ & $(-1.5973)$ \\
Durables only & 0.0011 & -0.0240 & 0.0400 & 0.3986 & -0.0932 \\
& $(1.3891)$ & $(-3.6887)$ & $(0.3967)$ & $(0.8497)$ & $(-0.8457)$ \\
Non-durables only & 0.0006 & -0.0104 & 0.1984 & 0.2720 & -0.1067 \\
& $(0.7962)$ & $(-1.3371)$ & $(1.5376)$ & $(0.7806)$ & $(-1.1885)$ \\
\hline
\end{tabular}




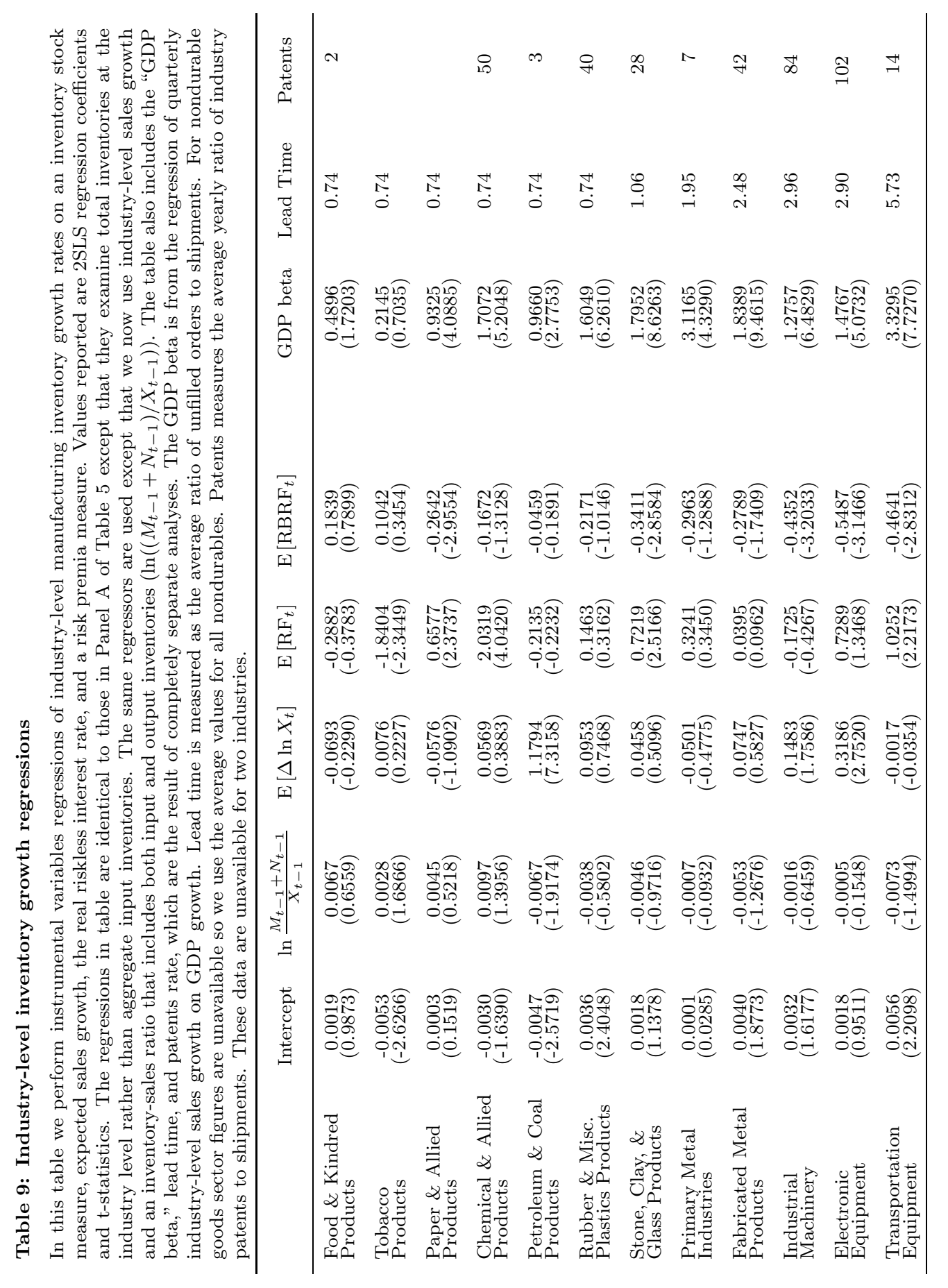


Table A1: Corresponding M3 and PPI series

\begin{tabular}{|c|c|c|c|c|}
\hline Industry name & SIC & NAICS & Deflator code & PPI Series \\
\hline Stone, clay, and glass & $32 \mathrm{M}$ & $27 \mathrm{~S}$ & wpu13 & Nonmetallic mineral products \\
\hline \multirow[t]{2}{*}{ Primary metals } & $33 \mathrm{M}$ & $31 \mathrm{~S}$ & wpu101 & Iron and steel \\
\hline & & & wpu1022 & Primary nonferrous metals \\
\hline \multirow[t]{2}{*}{ Fabricated metals } & $34 \mathrm{M}$ & $32 \mathrm{~S}$ & wpu107 & Fabricated structural metal products \\
\hline & & & wpu108 & Miscellaneous metal products \\
\hline \multirow[t]{2}{*}{ Industrial machinery } & $35 \mathrm{M}$ & $33 \mathrm{~S}$ & wpu11 & Machinery and equipment \\
\hline & & & wpu117 & Electrical machinery and equipment \\
\hline \multirow[t]{3}{*}{ Electronic equipment } & $36 \mathrm{M}$ & $34 \mathrm{~S}+35 \mathrm{~S}$ & wpu117 & Electrical machinery and equipment \\
\hline & & & wpu124 & Household appliances \\
\hline & & & wpu125 & Home electronic equipment \\
\hline Transportation equipment & $37 \mathrm{M}$ & $36 \mathrm{~S}$ & wpu141 & Motor vehicles and equipment \\
\hline Food & $20 \mathrm{M}$ & $11 \mathrm{~S}+12 \mathrm{~A}$ & wpusop2110 & Food manufacturing \\
\hline Tobacco & $21 \mathrm{M}$ & $12 \mathrm{~B}$ & wpu152 & Tobacco products \\
\hline Paper & $26 \mathrm{M}$ & $22 \mathrm{~S}$ & wpu0913 & Paper \\
\hline Chemicals & $28 \mathrm{M}$ & $25 \mathrm{~S}$ & wpu061 & Industrial chemicals \\
\hline Petroleum products & $29 \mathrm{M}$ & $24 \mathrm{~S}$ & wpu057 & Petroleum products, refined \\
\hline Rubber & $30 \mathrm{M}$ & $26 \mathrm{~S}$ & wpu07 & Rubber and plastic products \\
\hline All manufacturing & & & wpudur0200 & Manufactured goods \\
\hline All durable manufacturing & & & wpudur0211 & Durable manufactured goods \\
\hline All nondurable manufacturing & & & wpudur0222 & Nondurable manufactured goods \\
\hline
\end{tabular}


Figure 1A: Durable goods

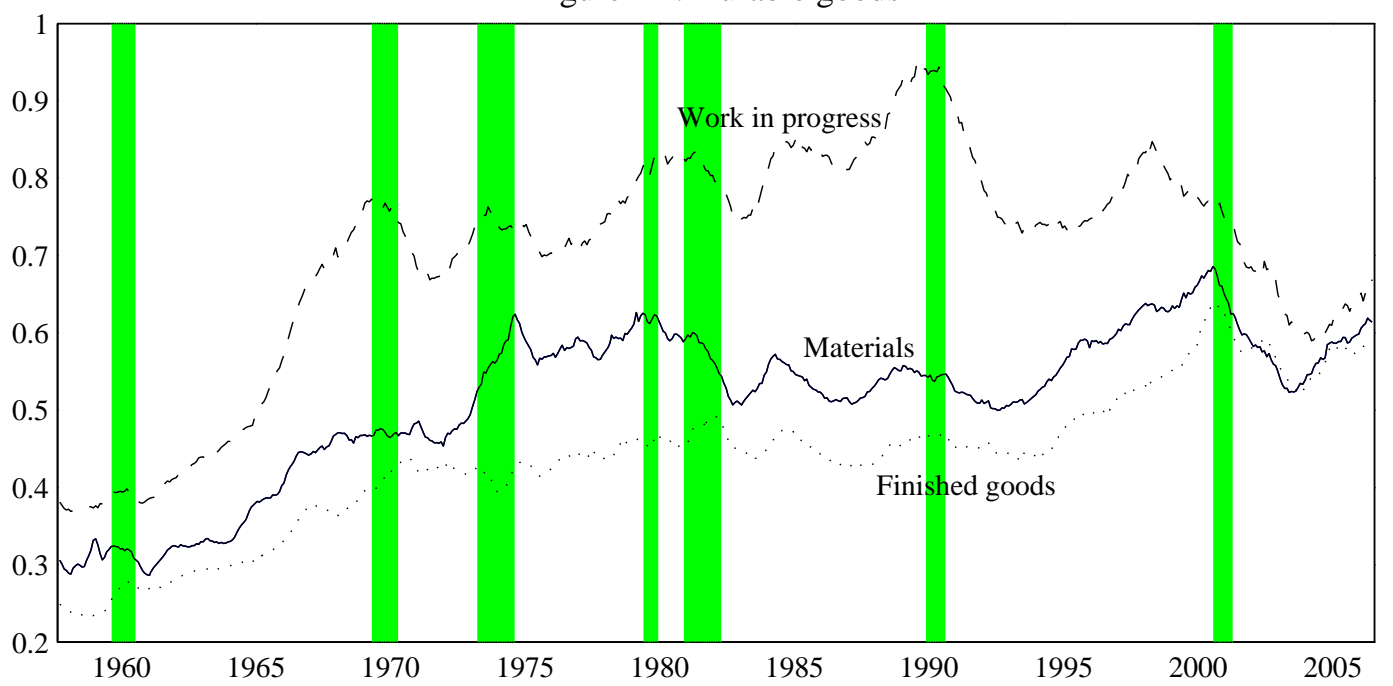

Figure 1B: Nondurable goods

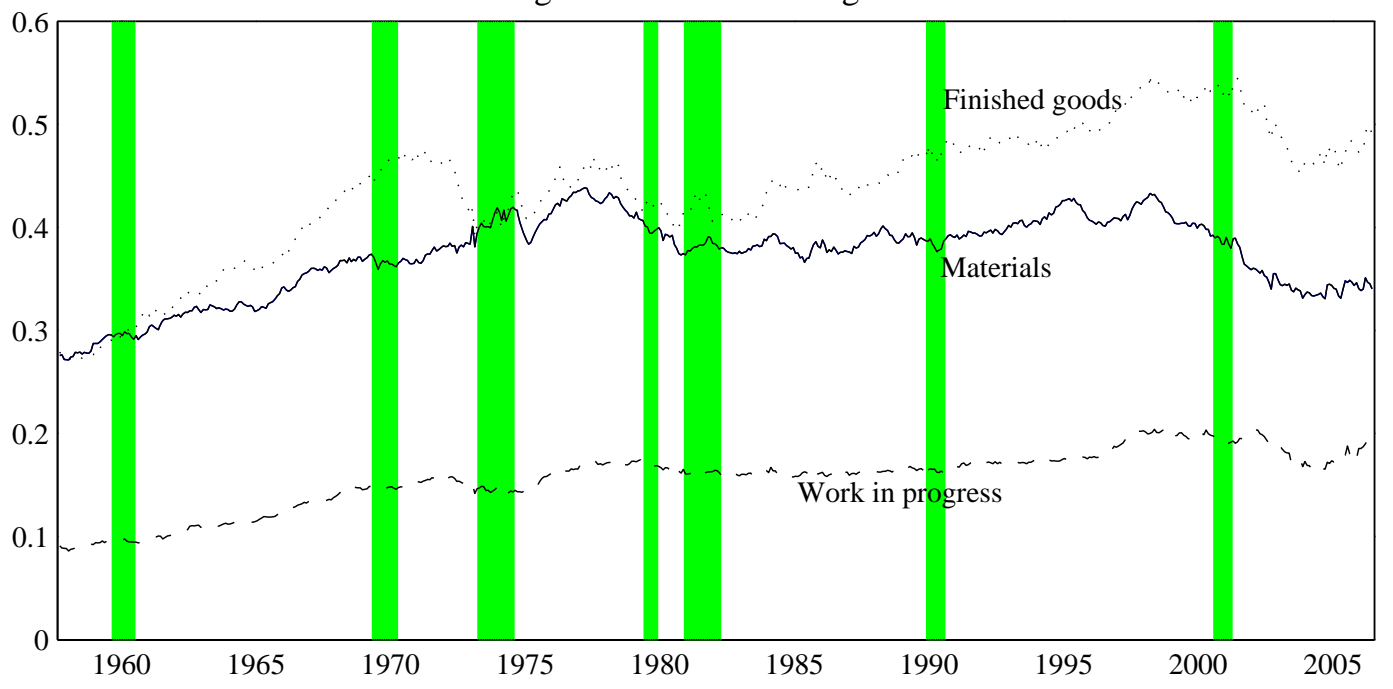

This figure shows time series of the stocks of the six components of U.S. manufacturing inventories. Shaded areas denote NBER recessions. The figure covers the period from 1958M2 to 2006M12. 
Figure 2

Ex ante real interest rates and stock and bond risk premia

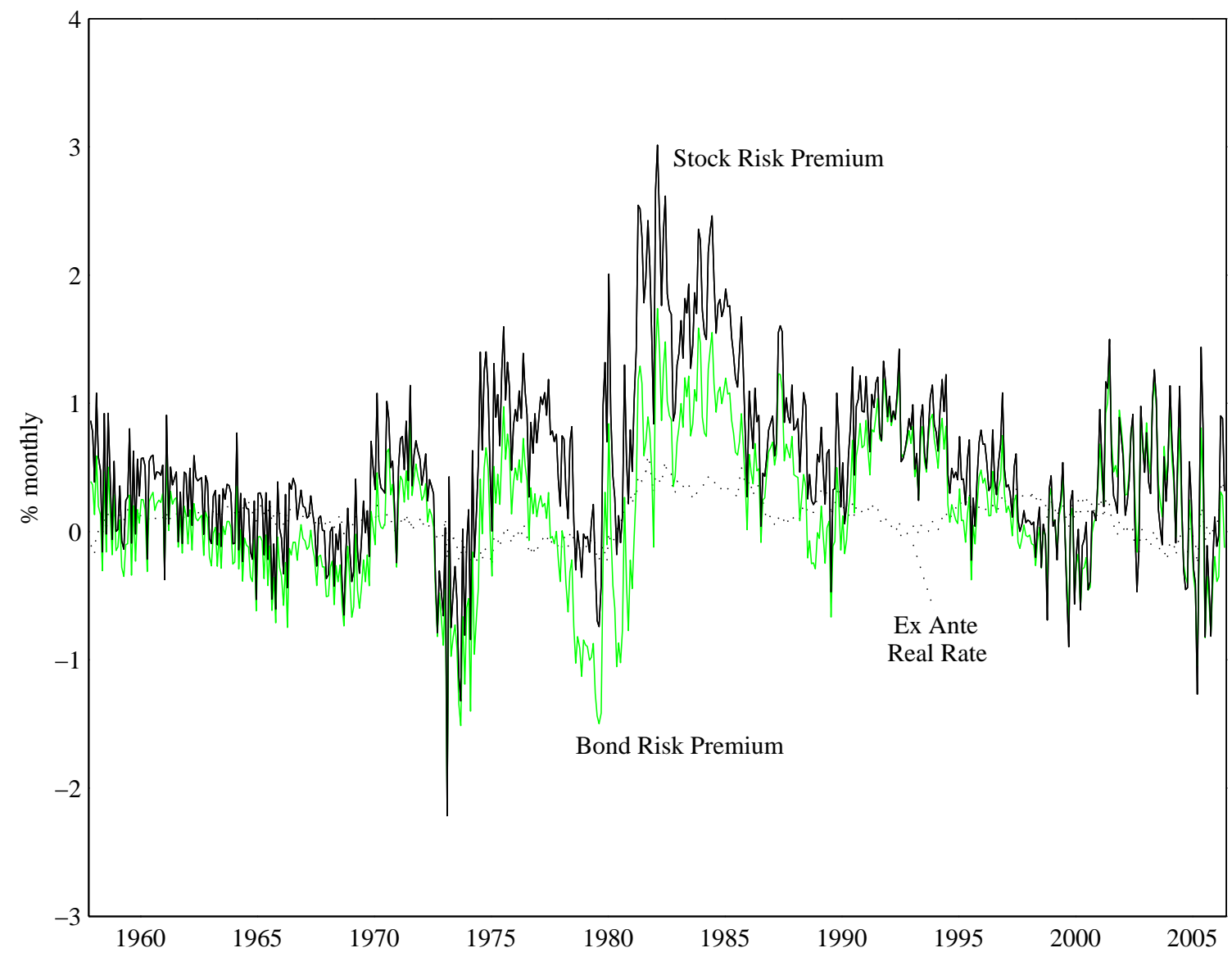

This figure shows time series plots of estimated ex ante real interest rates and risk premia on U.S. equities and corporate bonds. These are fitted values from regressions of realized one-month rates and excess returns on a set of lagged predictive variables. The regressions used are the restricted specifications reported in Table 4. The figure covers the period from 1958M2 to 2006M12. 
Figure 3

Cross-sectional relationship between shipment growth betas and the sensitivity of inventory investment to the cost of capital

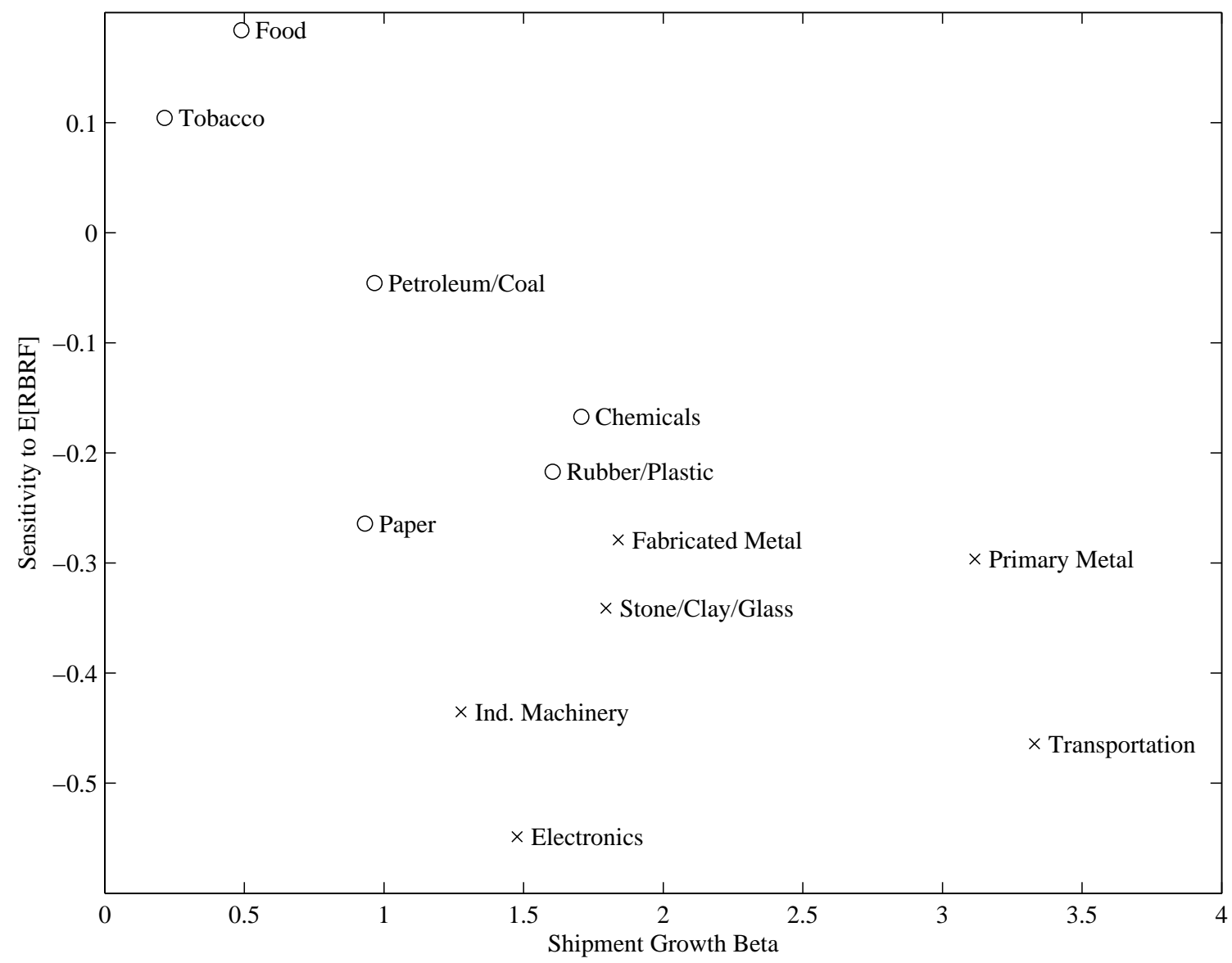

This figure shows the relation between the slope coefficient of a regression of quarterly industry sales growth rates on GDP growth and the sensitivity of inventory investment to the cost of capital. This sensitivity is measured by the coefficient on $\mathrm{E}[R B R F]$ in the regressions of inventory growth reported in Table 9. Both values are computed using data from 1958M2 to 2006M12. Industries that primarily produce nondurables are identified by an "o", while durable-producing industries are marked with an "x". 